\title{
Artificial recharge of groundwater: hydrogeology and engineering
}

\author{
Herman Bouwer
}

\begin{abstract}
Artificial recharge of groundwater is achieved by putting surface water in basins, furrows, ditches, or other facilities where it infiltrates into the soil and moves downward to recharge aquifers. Artificial recharge is increasingly used for short- or long-term underground storage, where it has several advantages over surface storage, and in water reuse. Artificial recharge requires permeable surface soils. Where these are not available, trenches or shafts in the unsaturated zone can be used, or water can be directly injected into aquifers through wells. To design a system for artificial recharge of groundwater, infiltration rates of the soil must be determined and the unsaturated zone between land surface and the aquifer must be checked for adequate permeability and absence of polluted areas. The aquifer should be sufficiently transmissive to avoid excessive buildup of groundwater mounds. Knowledge of these conditions requires field investigations and, if no fatal flaws are detected, test basins to predict system performance. Waterquality issues must be evaluated, especially with respect to formation of clogging layers on basin bottoms or other infiltration surfaces, and to geochemical reactions in the aquifer. Clogging layers are managed by desilting or other pretreatment of the water, and by remedial techniques in the infiltration system, such as drying, scraping, disking, ripping, or other tillage. Recharge wells should be pumped periodically to backwash clogging layers. Electronic supplementary material to this paper can be obtained by using the Springer LINK server ocated at http://dx.doi.org/10.1007/s10040-001-0182-4.
\end{abstract}

Received: 5 January 2001 / Accepted: 2 July 2001

Published online: 26 January 2002

(C) Springer-Verlag 2002

Electronic supplementary material to this paper can be obtained by using the Springer LINK server located at http://dx.doi.org/ 10.1007/s10040-001-0182-4.

H. Bouwer (

USDA-ARS, US Water Conservation Laboratory,

4331 E. Broadway Rd., Phoenix, Arizona 85040, USA

e-mail: hbouwer@uswcl.ars.ag.gov

Fax: 602-437-5291
Résumé La recharge artificielle des nappes est réalisée à partir d'eau de surface dans des bassins, des tranchées, des fossés et d'autres dispositifs où l'eau s'infiltre dans le sol et s'écoule vers le bas pour recharger les aquifères. La recharge artificielle est utilisée de plus en plus pour stocker l'eau souterraine à court et à long terme, là où cela présente des avantages sur le stockage d'eaux de surface, et pour le recyclage des eaux usées. La recharge artificielle nécessite des sols perméables en surface. Lorsque ce n'est pas le cas, on peut utiliser des tranchées ou des puits dans la zone non saturée, ou bien on peut injecter directement l'eau dans les aquifères à partir de puits. Pour réaliser un système destiné à la recharge artificielle de nappe, les taux d'infiltration du sol doivent être déterminés et on doit contrôler que la zone non saturée entre la surface et l'aquifère présente une perméabilité adéquate et ne possède pas de zones polluées. L'aquifère doit être suffisamment transmissif afin d'éviter l'apparition de dômes piézométriques excessifs. La connaissance de ces conditions nécessite des études de terrain et, si aucun défaut fatal n'est détecté, des bassins tests pour prévoir les performances du système. La qualité des eaux introduites doit être évaluée, en particulier en ce qui concerne la formation de colmatages au fond des bassins ou d'autres dispositifs d'infiltration, ainsi que les réactions géochimiques au sein de l'aquifère. Les colmatages sont évités par décantation ou par un autre pré-traitement de l'eau, et par des techniques d'entretien du système d'infiltration, comme le séchage, le raclage, le passage de disques, de herse ou d'autres instruments de labour. Les puits de recharge doivent être pompés périodiquement pour les décolmater.

Resumen La recarga artificial de acuíferos consiste en disponer agua superficial en balsas, surcos, zanjas o cualquier otro tipo de dispositivo, desde donde se infiltra y alcanza el acuífero. La recarga artificial experimenta un uso creciente para almacenar agua a corto o largo plazo, ya que presenta varias ventajas con respecto al almacenamiento en superficie, así como para reutilización. La recarga artificial requiere suelos permeables, por lo que se debe recurrir a zanjas o minas en la zona no saturada, o bien inyectar el agua directamente en el acuífero por medio de pozos. Para diseñar un sistema de recarga artificial, se debe determinar la tasa de infiltración del suelo y verificar que la zona no saturada entre la su- 
perficie del terreno y el acuífero tiene una permeabilidad adecuada, y que no existe zonas contaminadas. El acuífero debe ser suficientemente transmisivo para evitar un ascenso excesivo del nivel piezométrico. El conocimiento de estas condiciones requiere investigaciones de campo y, si no se detecta inconvenientes graves, ensayos con balsas para predecir el rendimiento del sistema. Los aspectos de calidad del agua también han de ser evaluados, especialmente en lo que respecta a la formación de capas colmatantes en el fondo de las balsas u otras superficies de infiltración y a las reacciones geoquímicas en el acuífero. Las capas colmatantes se pueden evitar mediante el filtrado u otros pretratamientos del agua, así como mediante la restauración de la capacidad de infiltración del sistema con técnicas como el secado, retirada, lijado, escarificado u otras técnicas de roturación. Los pozos de recarga deben ser bombeados periódicamente para desprender los materiales colmatantes.

Keywords Artificial recharge - Groundwater management · Groundwater recharge · Unsaturated zone · Water reuse

\section{Introduction}

Artificial recharge systems are engineered systems where surface water is put on or in the ground for infiltration and subsequent movement to aquifers to augment groundwater resources (Fig. 1). Other objectives of artificial recharge are to reduce seawater intrusion or land subsidence, to store water, to improve the quality of the water through soil-aquifer treatment or geopurification, to use aquifers as water conveyance systems, and to make groundwater out of surface water where groundwater is traditionally preferred over surface water for drinking. Infiltration and artificial recharge are achieved by ponding or flowing water on the soil surface with basins, furrows, ditches, etc. (Figs. 1 and 2); by placing it in infiltration trenches, shafts, or wells in the vadose zone (Fig. 3); or by placing it in wells for direct injection into the aquifer. Other forms of groundwater recharge include natural, enhanced, induced, and incidental recharge.

Natural recharge is how natural (meteoric) groundwater is formed as the difference between water inputs into the soil (precipitation and infiltration from streams, lakes, or other natural water bodies) and outputs (evapotranspiration plus runoff). Natural recharge is typically about $30-50 \%$ of precipitation in temperate humid climates, 10-20\% of precipitation in Mediterranean type climates, and about $0-2 \%$ of precipitation in dry climates (Bouwer 1989, 2000c, and references therein; Tyler et al. 1996). Natural recharge rates are reflected by groundwater ages, which vary from a few hours or days in wetweather springs or very shallow groundwater in high rainfall areas, to tens of thousands of years or more in dry climates with deep groundwater levels (Tyler et al. 1996) or in confined aquifers at considerable distances

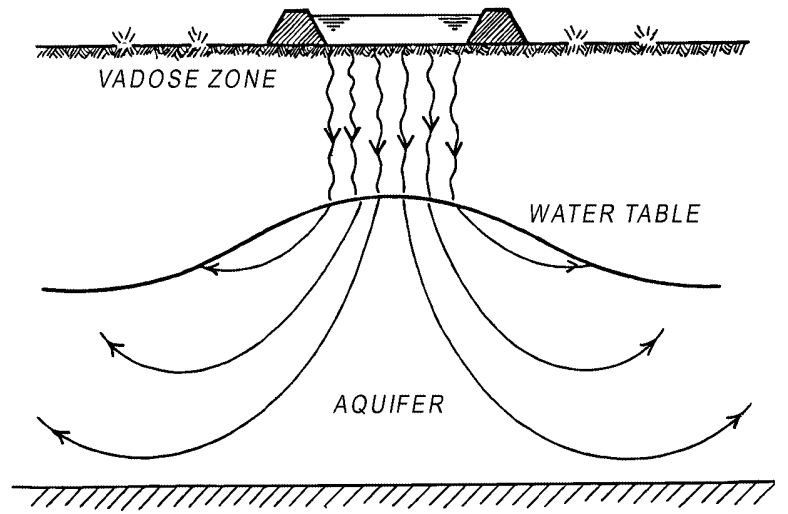

Fig. 1 Section through a typical groundwater recharge system with infiltration basin and groundwater mound below the basin

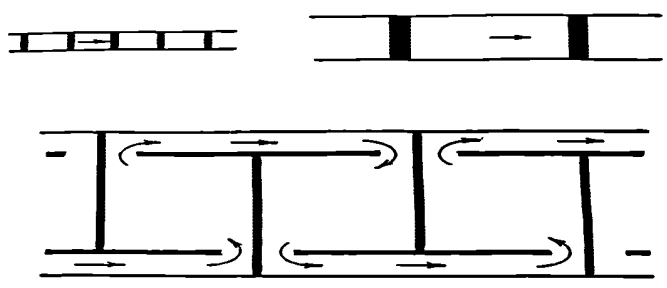

Fig. 2 Plan views of in-channel infiltration systems with low weirs in narrow, steep channel (upper left); bigger dams in wider, more gently sloping channel (upper right); and T-levees in wide, flat channels (bottom)

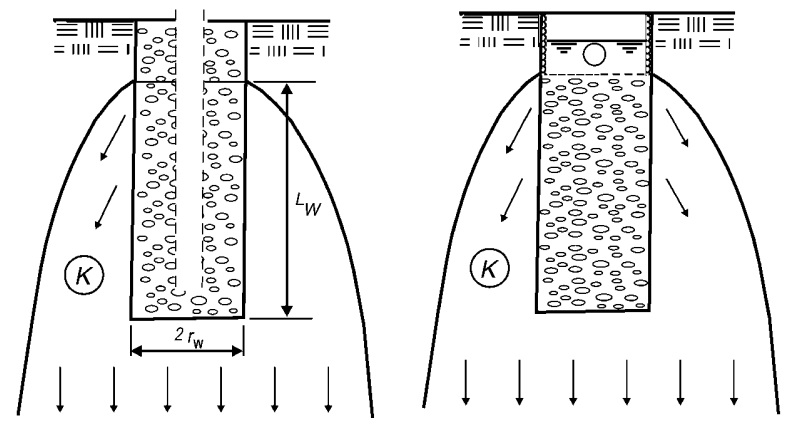

Fig. 3 Sections showing vadose-zone recharge well (left) with sand or gravel fill and perforated supply pipe; and recharge trench (right) with sand or gravel fill, supply pipe on top of fill, and cover. Arrows represent downward flow in wetted zone with hydraulic conductivity $\mathrm{K}$

from their outcrops where they are recharged. Groundwater is an extremely important water resource, for it comprises more than $98 \%$ of all the world's liquid fresh water (Bouwer 1978, and references therein).

Enhanced recharge consists mainly of vegetation management to replace deep-rooted vegetation by shallow-rooted vegetation or bare soil, or by changing to plants that intercept less precipitation with their foliage, thus increasing the amount of water that reaches the soil. In wooded areas, this is achieved, for example, by replacing conifers with deciduous trees (Querner 2000). Induced recharge is achieved by placing wells relatively 
close to streams or rivers, so that more river water is "pulled" into the aquifer as water tables near the streams are lowered by pumping the wells. The main objective of these "bank filtration" systems is often to get pretreatment of the river water as it moves through the river-bottom materials and the aquifers before it is pumped up for conventional drinking-water treatment and public water supply. Bank filtration is used particularly where river water is contaminated or where the public prefers groundwater over surface water (Kühn 1999).

Incidental recharge is caused by human activities that are not intended for recharge of groundwater as such. These activities include sewage disposal by septic-tank leach fields or cesspits, and drainage or deep percolation from irrigated fields. Such drainage of irrigation water is necessary to prevent salt accumulation in the root zone. In dry climates, drainage is achieved by applying more irrigation water than needed for crop water use (evapotranspiration or consumptive use). Because the salts and other chemicals in the irrigation water are then leached out of the root zone with much less water than the irrigation water applied, the salt content in the leaching or drainage water is much higher than in the irrigation water itself. This condition, as well as the presence of agricultural and other chemicals in the deep-percolation water from irrigated fields, degrades the quality of the underlying groundwater (Bouwer et al. 1999a; Bouwer 2000b).

Another form of incidental recharge is obtained with urbanization, where most of the land is covered with streets, driveways, roofs, and other impermeable surfaces that produce more runoff and have much less evapotranspiration than the natural surfaces. This recharge could be significant in semi-arid areas, where rain typically falls in small amounts that do not penetrate the soil very deeply, so that most of the water evaporates. With urbanization, however, more runoff is produced, which can be collected for on-site storage and artificial recharge, or it flows naturally to ephemeral streams where it infiltrates into the soil and moves down to the groundwater (Lerner 2002).

Artificial recharge is expected to become increasingly necessary in the future as growing populations require more water, and as more storage of water is needed to save water in times of water surplus for use in times of water shortage. The traditional way of storing water has been with dams. However, good dam sites are becoming scarce. In addition, dams have various disadvantages, such as evaporation losses (about $2 \mathrm{~m} /$ year in warm, dry climates); sediment accumulation; potential of structural failure; increased malaria, schistosomiasis, and other human diseases; and adverse ecological, environmental, and socio-cultural effects (Devine 1995; Knoppers and van Hulst 1995; Pearce 1992). New dams are often more and more difficult to build because of high cost and public opposition. Consideration is being given to destroying some dams, which is no easy task, especially if they are fairly large and have a lot of appurtenances like water intakes, shore developments, etc. (Tatro 1999).
Dams interfere with the river ecology and can flood sensitive areas (cultural, religious, archeological, environmental, recreational, scenic, etc.). People living on the reservoir area of new dams have to relocate. Dams are not sustainable because eventually most, if not all, silt up, and because of evaporation they are not effective for long-term storage of water (years or decades). Such long-term storage might become increasingly necessary as increases of carbon dioxide and other greenhouse gases in the atmosphere cause global climatic changes that increase the probability of extremes in weather, such as more frequent droughts and excessive rain. These conditions, along with increasing populations, increase the need for storing excess water in wet periods to meet water demands in dry periods.

Underground storage via artificial recharge has the advantage of essentially zero evaporation from the aquifer. Often economic and other aspects of recharge are also favorable. For these reasons, the practice of artificial recharge is rapidly increasing in many parts of the world. These aspects are discussed by Asano (1985) and in the proceedings of international recharge symposia that were held in California in 1988, in Florida in 1994 (proceedings of both symposia are available from the American Society of Civil Engineers in Reston, Virginia, USA), and in Amsterdam in 1998 (Peters 1998). The next international symposium on this topic is planned for Adelaide, Australia, in 2002.

Water sources for artificial recharge include water from perennial or intermittent streams that might or might not be regulated with dams, storm runoff (including from urban areas), aqueducts or other water-conveyance facilities, irrigation districts, drinking-water treatment plants, and sewage-treatment plants. Artificial recharge of groundwater is expected to play an increasingly important role in water reuse, because it gives "soilaquifer treatment," or geopurification of the effluent as it moves through soils and aquifers. Recharge also eliminates the undesired pipe-to-pipe or "toilet-to-tap" connection between the sewage-treatment plant and the water-supply system where municipal waste water is used to augment drinking-water supplies. This factor makes potable-water reuse aesthetically much more acceptable to the public. Recharge also makes water reuse possible where religious taboos exist against certain direct uses of "unclean" water, as in Islamic countries (Ishaq and Khan 1997; Warner 2000), and in New Zealand, where the Maoris require wastes to pass through soil before they enter streams or lakes.

Of all the water in the world, $97 \%$ is salt water in the oceans (Bouwer 1978, and references therein). Of the remaining fresh water, two-thirds is in the form of ice in arctic and mountainous regions. Of the remaining liquid fresh water, less than $2 \%$ is surface water in streams and lakes, and much of that is fed by groundwater. More than $98 \%$ of the world's liquid fresh water thus is groundwater. Not only is groundwater the dominant water resource, aquifers also offer vast opportunities for underground storage of water. 


\section{Artificial Recharge Systems}

\section{Surface Infiltration}

Surface infiltration systems for artificial recharge are divided into in-channel and off-channel systems. Inchannel systems consist of dams placed across ephemeral or perennial streams to back the water up and spread it out, thus increasing the wetted area of the streambed or floodplain so that more water infiltrates into the ground and moves down to the groundwater (Fig. 2). Some dams consist of low weirs spaced a small distance apart; others are larger dams spaced a greater distance apart (Fig. 2, top). The larger dams often need considerable spillway capacity to pass large flows. Sometimes they have a sacrificial section that washes out during high flows and is replaced when the flood danger is over. Steel weirs, earth dams, concrete dams, or inflatable rubber dams are used. The latter are injected with water or air; air is generally preferred. Air pressures are relatively low (about $10 \mathrm{psig}$, or $1.5 \mathrm{kPa}$ ). When inflated, some water can spill over the dam, but for the big floods they are deflated to lie flat on their foundation. Where channels have small slopes and water depths, water is spread over the entire width of the channel or floodplain by placing T- or L-shaped earthen levees about $1 \mathrm{~m}$ high in the channel (Fig. 2, bottom). These levees are pushed up by bulldozers using natural streambed sands. When the levees are washed out by high flows, they are restored by the bulldozers. Off-channel surface recharge systems consist of specially constructed infiltration basins (Fig. 1), lagoons, old gravel pits, flood-irrigated fields, perforated pipes, or any other facility where water is put or spread on the ground for infiltration into the soil and movement to underlying groundwater.

Water sources for in- and off-channel recharge systems should be of adequate quality to prevent undue clogging of the infiltrating surface by deposition and accumulation of suspended solids (sediment, algae, and sludge); by formation of biofilms and biomass on and in the soil; by precipitation of calcium carbonate or other salts on and in the soil; and by formation of gases that stay entrapped in the soil, where they block pores and reduce the hydraulic conductivity. Gases sometimes also accumulate under the clogging layer, where they form a vapor barrier to downward flow. One source of these gases is dissolved air in the infiltrated water. The air goes out of the solution:

1. as the water pressure drops from a pressure head equal to the water depth above the soil surface to a negative pressure head in the unsaturated zone below the clogging layer; or

2. where the soil or aquifer is warmer than the infiltrating water itself.

Also, gases are formed by microbiological activity in the soil, such as nitrogen gas produced by denitrification and methane produced by methanosarcina and other methanogens in the Archeabacteria group.
Clogging of the infiltrating surface and resulting reductions in infiltration rates are the bane of all artificial recharge systems (Baveye et al. 1998; Bouwer et al. 2001; Bouwer and Rice 2001). Pretreatment of the water to reduce suspended solids, nutrients, and organic carbon, and regular drying of the system to enable drying and cracking of the clogging layer and physical removal of the clogging layer might be necessary to minimize clogging effects. However, even when suspended solids, nutrients, and organic carbon are mostly removed from the water, clogging still is likely to occur because of microbiological growth on the infiltrating surface (Baveye et al. 1998). For example, such cloggings have been observed in laboratory infiltration studies in the dark with high-quality tap water (Bouwer and Rice 2001).

Surface infiltration systems normally require permeable surface soils to get high infiltration rates and to minimize land requirements. Where permeable soils occur deeper down and the less permeable overburden is not very thick, the overburden can be removed so that the basin bottom is in the more permeable material. Vadose zones should be free from layers of clay or other fine-textured materials that unduly restrict downward flow and form perched groundwater that waterlogs the recharge area and reduces infiltration rates. Perched water can also form on aquitards where aquifers are semi-confined. Aquifers should be unconfined and sufficiently transmissive to accommodate lateral flow of the infiltrated water away from the recharge area without forming high groundwater mounds that interfere with the infiltration process. Also, soils, vadose zones, and aquifers should be free from undesirable contaminants that can be transported by the water and move to aquifers or other areas where they are not wanted.

\section{Vadose-Zone Infiltration}

Where sufficiently permeable soils and/or sufficient land areas for surface infiltration systems are not available, groundwater recharge can also be achieved with vertical infiltration systems, such as trenches or wells in the vadose zone. Recharge trenches are dug with a backhoe and are typically less than about $1 \mathrm{~m}$ wide and up to about $5 \mathrm{~m}$ deep (Fig. 3). They are backfilled with coarse sand or fine gravel. Water normally is applied through a perforated pipeline on the surface of the backfill, and the trench is covered to blend in with the surroundings. For example, a layer of topsoil for grass or other plantings is placed on top of the backfill to blend in with landscaping, or concrete slabs or other paving are added where the area is paved. Sand-filled ditches have been tested in agricultural areas in Jordan to intercept surface runoff for deeper infiltration into the vadose zone (Abu-Zreig et al. 2000).

Vadose-zone wells (also called recharge shafts or dry wells) are normally installed with a bucket auger, and they are about $1 \mathrm{~m}$ in diameter and as much as $60 \mathrm{~m}$ deep (Fig. 3). The wells are also backfilled with coarse sand or fine gravel. Water is normally applied through a 
perforated or screened pipe in the center. Free-falling water in this pipe should be avoided to avoid air entrainment in the water and formation of entrapped air in the backfill and the soil around the vadose-zone well. To do this, water is supplied through a smaller pipe inside the screened or perforated pipe that extends to a safe distance below the water level in the well. Pipes with various diameters also can be installed. Water is then applied through the pipe that gives sufficient head loss to avoid free-falling water. Also, a special orifice type of valve can be placed at the bottom of the supply pipe that can be adjusted to restrict the flow enough to avoid free-falling water.

The main advantage of recharge trenches or wells in the vadose zone is that they are relatively inexpensive. The disadvantage is that eventually they clog up at their infiltrating surface because of accumulation of suspended soils and/or biomass. Because they are in the vadose zone, they cannot be pumped for "backwashing" the clogging layer, or redeveloped or cleaned to restore infiltration rates. To minimize clogging, the water should be pretreated to remove suspended solids. For recharge trenches, pretreatment is accomplished in the trench itself by placing a sand filter with possibly a geotextile filter fabric on top of the backfill. Where this would reduce the flow into the backfill too much, the recharge trench could be widened at the top to create a T-trench with a larger filter area than the surface area of the trench itself. Economically, the choice is between pretreatment to extend the useful life of the trench or vadose-zone well, and constructing new ones. The old trenches or wells can then be abandoned, or they can continue to be used to take advantage of whatever residual recharge they still give. If the clogging is predominantly organic, some recovery in infiltration capacity might be achieved by very long drying or "resting" periods, perhaps on the order of a year or so.

\section{Wells}

Direct recharge or injection wells are used where permeable soils and/or sufficient land area for surface infiltration are not available, vadose zones are not suitable for trenches or wells, and aquifers are deep and/or confined. Truly confined aquifers might still be rechargeable, because such aquifers accept and yield water by expansion and compression of the aquifer itself and, particularly, of interbedded clay layers and aquitards that are more compressible than the sands and gravels or consolidated materials of the aquifer. However, excessive compression of aquifer materials by overpumping is mostly irreversible (Bouwer 1978, and references therein). Recharge might also be possible through semi-confining layers. However, this situation creates quality deterioration in the lower aquifer if the groundwater above the aquitard is of low quality due to irrigation, septic-tank leach fields, and other incidental recharges.

In the USA, the water used for well injection is usually treated to meet drinking-water quality standards for two reasons. One is to minimize clogging of the well-aquifer interface, and the other is to protect the quality of the water in the aquifer, especially where it is pumped by other wells in the aquifer for potable uses. Where groundwater is not used for drinking, water of lower quality can be injected into the aquifer. For example, in Australia stormwater runoff and treated municipal waste-water effluent are injected into brackish aquifers to produce water for irrigation by pumping from the same wells. Clogging is then alleviated by a combination of low-cost water treatment and well redevelopment, and groundwater quality is protected for its declared beneficial uses (Dillon and Pavelic 1996; Dillon et al. 1997). These aquifer storage and recovery operations have been successfully going on since 1993 in South Australia, and the number and size of the projects are expanding, using limestone, fractured rock, and alluvial aquifers.

Unconsolidated aquifers tend to be relatively coarse textured (sands and gravels) and are saturated; these materials do not give the same quality improvement of the recharge water as the finer-textured, unsaturated soils below surface and vadose-zone infiltration systems. Also, the water used for well injection in the USA is often chlorinated and has a chlorine residual of about $0.5 \mathrm{mg} / \mathrm{l}$ when it goes into the recharge well. Thus, whereas secondary sewage effluent can readily be used in surface infiltration systems for soil-aquifer treatment and eventual potable reuse, effluent for well injection should at least receive tertiary treatment (sand filtration and chlorination). This treatment removes remaining suspended solids and protozoa, like giardia, and cryptosporidium and parasites, like helminth eggs, by filtration; and bacteria and viruses by chlorination, ultra violet irradiation, or other disinfection. In the USA the tertiary effluent is often further processed with membrane filtration (microfiltration and reverse osmosis) to remove any pathogens that might have escaped the tertiary treatment, and also nitrogen, phosphorus, organic carbon, and other chemicals. Dissolved salts also are almost completely removed. With all these removals, clogging problems still commonly occur when this water is used for groundwater recharge through wells. Geochemical compatibility between the recharge water and the existing groundwater (carbonate precipitation, iron hydroxide formation, mobilization of mineral chemicals, etc.) must also be considered. In Australia, where stormwater has been seasonally injected into aquifers, pathogen attenuation rates in aquifers are adequate for irrigation use and generally also meet local requirements for potable use of recovered water (Dillon and Pavelic 1996).

Although clogged recharge wells can be redeveloped and rehabilitated with conventional techniques, a better approach is to prevent serious clogging by frequent pumping of the well, for example, about $15 \mathrm{~min}$ of pumping once, twice, or three times per day. This frequent "backwashing" of the clogging layer, which, of course, requires a dedicated pump in the well, often prevents serious clogging. As a matter of fact, the frequent backwashing might eliminate the need for membrane 
filtration. In one project near Phoenix, Arizona, USA, for example, well recharge with sewage effluent after primary and secondary treatment, nitrification-denitrification, filtration, and UV disinfection has shown no signs of clogging in the three years of operation of recharge wells that were pumped for about $30 \mathrm{~min}$ three times a day (Fred Goldman, GTA Engineering, Inc., Phoenix, AZ, personal communication 2001). Similarly in Australia, the redevelopment is tuned to the sediment and organic loading of the well with very positive results (Dillon and Pavelic 1996). Thus, frequent pumping of injection wells might be more effective than membrane filtration treatment of the water to prevent well clogging.

\section{Combination Systems}

Whenever possible, surface infiltration systems are preferred, because they offer the best opportunity for clogging control and the best soil-aquifer treatment if quality improvement of the water is of importance. If permeable soils occur at the ground surface or within excavatable depth, the water can directly move into the coarse soils. However, where deeper fine-textured layers significantly restrict the downward movement of the water to the aquifer, and perched groundwater rises too high, surface infiltration can still be used if vertical infiltration systems are installed through the restricting layer (Fig. 4). The upper parts of the systems then function as drainage systems of the perched groundwater, while the lower parts function as systems for infiltration and recharge of the aquifer. If the bottom of the restricting layer is not too deep (less than $3 \mathrm{~m}$, for example), trenches can be used to drain the perched water and send it down to the aquifer (Fig. 4, left). For deeper restricting layers (up to about $40 \mathrm{~m}$ ) vadose-zone wells can be used (Fig. 4, center), whereas conventional wells can be used where the restricting layers are beyond reach of bucket augers (Fig. 4, right). The wells would then be screened above and below the restricting or confining layer.

The advantage of the systems shown in Fig. 4 is that the water has been prefiltered through the soil and the perched groundwater zone, so that its clogging potential is significantly reduced. Even then, if the lower part of the system extends into the aquifer, as in Fig. 4 (right), it would probably be good practice to regularly pump the well. Water-quality issues also must be considered, particularly where the water above the restricting layer is of lower quality than that in the aquifer itself.

The principle of draining perched groundwater for recharge of underlying aquifers with systems such as shown in Fig. 4 has not been adequately tested in the field. Thus, pilot testing of these systems should always be done to see if they work satisfactorily and how they should best be managed before large projects are installed and considerable amounts of money are invested. Pilot testing also is desirable for the simpler systems of basins, trenches, vadose-zone wells, and aquifer wells, because how these systems perform and how they should be designed and managed depends very much on local
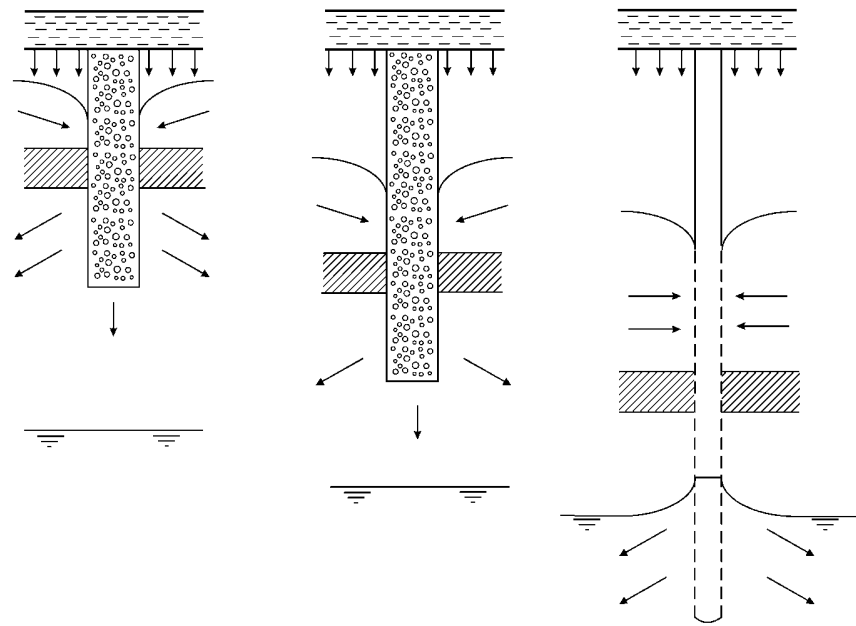

Fig. 4 Sections showing surface infiltration systems with restricting layer (hatched) and perched groundwater draining to unconfined aquifer with trench (left), vadose-zone well (center), and aquifer well (right)

conditions of soil, hydrogeology, climate, and water quality. The golden rule in artificial recharge is to start small, learn as you go, and expand as needed.

\section{Design and Management}

\section{Infiltration Rates}

Surface infiltration systems require permeable soils and vadose zones to get the water into the ground and to the aquifer, and unconfined and sufficiently transmissive aquifers to get lateral flow away from the infiltration system without excessive groundwater mounding. Thus, soil maps and hydrogeologic reports are used to do the first screening and to select promising sites. Depending on the relative amounts of clay $(<2 \mu \mathrm{m})$, silt $(2-50 \mu \mathrm{m})$, and sand $(>50 \mu \mathrm{m})$, the textural classification of soil can be evaluated from the soil-textural triangle (Fig. 5) prepared by the Soil Survey Staff of the U.S. Department of Agriculture and published in 1951. Typical hydraulicconductivity values of the various soils are (Bouwer 1999):

$\begin{array}{lr}\text { clay soils } & <0.1 \mathrm{~m} / \text { day } \\ \text { loams } & 0.2 \mathrm{~m} / \text { day } \\ \text { sandy loams } & 0.3 \mathrm{~m} / \text { day } \\ \text { loamy sands } & 0.5 \mathrm{~m} / \text { day } \\ \text { fine sands } & 1 \mathrm{~m} / \text { day } \\ \text { medium sands } & 5 \mathrm{~m} / \text { day } \\ \text { coarse sands } & >10 \mathrm{~m} / \text { day }\end{array}$

If the soil contains gravel, the bulk hydraulic conductivity of the soil-gravel mixture can empirically be estimated as (Bouwer and Rice 1984b):

$K_{b}=K_{s} e_{b} / e_{s}$

where $K_{b}$ is the bulk hydraulic conductivity of soilstones mixture, $K_{s}$ the hydraulic conductivity of the soil 


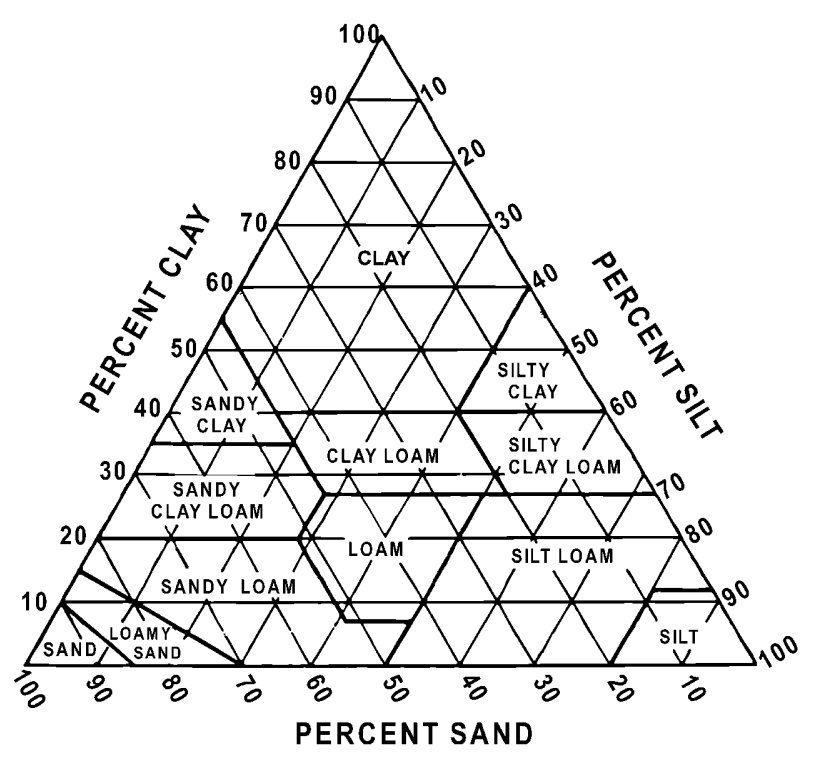

Fig. 5 Triangular chart showing the percentages of sand, silt, and clay in the basic soil-texture classes (From Soil Survey Staff 1951)

fraction alone, $e_{b}$ the bulk void ratio of soil-stones mixture, and $e_{s}$ the void ratio of soil alone.

This equation applies to a continuous soil matrix with the stones embedded therein. The stones are impermeable bodies in a soil matrix, which reduces its hydraulic conductivity relative to that of the soil without stones.

Applying Darcy's equation to a soil after it has been flooded with water (Fig. 6) yields (Bouwer 1978, and references therein):

$V_{i}=K \frac{H_{w}+L_{f}-h_{w e}}{L_{f}}$

where $V_{i}$ is the infiltration rate, $K$ the hydraulic conductivity of wetted zone, $H_{w}$ the water depth above soil, $L_{f}$ the depth of wetting front, and $h_{w e}$ the capillary suction or negative pressure head at wetting front.

This is the Green-and-Ampt equation for infiltration into a flooded soil. It was developed almost 100 years ago and is based on the assumption of piston flow (Green and Ampt 1911). Diffusion-based and empirical equations have also been developed (Bouwer 1978, and references therein). The term $v_{i}$ is the volumetric infiltration rate per unit of surface area. It can be visualized as the rate of decline of the water surface in an infiltration basin if inflow is stopped and evaporation is ignored. Because the wetted zone is not completely saturated but contains entrapped air, $K$ is less than $K_{s}$ at saturation, about $0.5 K_{s}$ for sandy soils, and $0.25 K_{s}$ for clays and loams (Bouwer 1978). The value of $h_{w e}$ is taken as the water-entry value of the soil. This parameter is the negative pressure head where water displaces most of the air on the curve relating soil-water content to soil-water pressure of the soil. Typical values of $h_{w e}$ are (in $\mathrm{cm}$ water; Bouwer et al. 1999b):

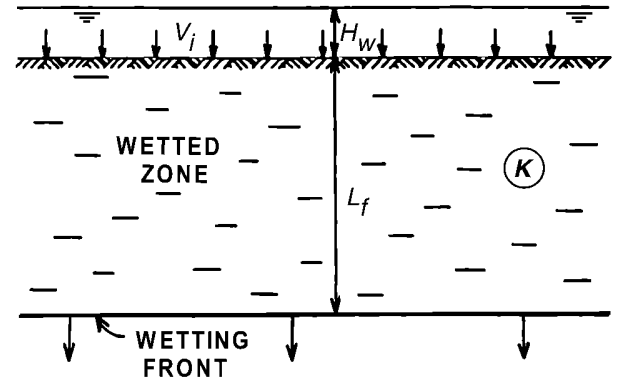

Fig. 6 Section showing geometry and symbols for Green and Ampt piston-flow model of infiltration

coarse sands $-5$

medium sands

$-10$

fine sands

$-15$

loamy sands-sandy loams

loams

$-25$

$-35$

structured clays

$-35$

dispersed clays

$-100$

Equation (2) shows that when the soil is first flooded, $L_{f}$ is small and $v_{i}$ is high. However, as the wet front moves downward and $L_{f}$ increases, the ratio in Eq. (2) approaches a value of unity, and the infiltration rate becomes numerically equal to $K$ of the wetted zone.

\section{Infiltrometers}

After soil and hydrogeologic surveys have identified potentially suitable sites for artificial recharge of groundwater with surface infiltration systems, "wet" infiltration tests should be performed to see what kind of infiltration rates can be expected, so that the land area needed for a certain volumetric recharge rate, or the recharge rate that can be achieved with a certain land area, can be estimated. Infiltration tests typically are done with metal, cylinder infiltrometers about $30 \mathrm{~cm}$ in diameter. However, use of such small infiltrometers often seriously overestimates the large-area infiltration rates because of lateral flow (divergence) below and around the cylinder due to capillary suction in the soil (Bouwer 1986; Bouwer et al. 1999b). Double-ring or "buffered" infiltrometers do not compensate for divergence, because the divergence also causes overestimation of infiltration in the center portion of the cylinder. The obvious approach then is to use larger infiltration test areas like, for example, $3 \times 3 \mathrm{~m}$ bermed areas, where divergence or "edge" effects are less significant. However, these tests are laborious and they also require large volumes of water, because it can take more than a day to reach or approach "final" infiltration rates. A better approach is to use conventional single cylinders with significant water depth to speed up the infiltration process, so that tests can be completed in a relatively short time ( $5 \mathrm{~h}$, for example). The extent of lateral wetting is measured using a shovel, and the depth of wetfront penetration is measured using a shovel or auger, or it is estimated from total accumulated infiltration and 
fillable porosity. The resulting infiltration data are then corrected for water depth in the cylinder, limited depth of soil wetting below the cylinder, and divergence outside the cylinder to get an estimate of the long-term infiltration rate for a large inundated area (Bouwer et al. $1999 b)$. This rate should be about equal to the hydraulic conductivity $K$ of the wetted zone.

The infiltrometers that have been used for this procedure are single steel cylinders $60 \mathrm{~cm}$ in diameter and $30 \mathrm{~cm}$ high with beveled edges (Fig. 7). A piece of $5 \times 10 \mathrm{~cm}$ lumber is placed on top of the cylinder and the cylinder is driven straight down with a sledge hammer to a depth of about $3-5 \mathrm{~cm}$ into the ground. The soil is packed against the inside and outside of the cylinder with a piece of $2.5 \times 5 \mathrm{~cm}$ wood that is held at an angle on the soil against the cylinder and tapped with a light hammer to achieve good soil-cylinder contact. If the soil contains clay, the water used for the test should be of the same chemical composition as the water used in the recharge project, to avoid errors due to effects of water quality on the status of the clay (coagulated or dispersed; Bouwer 1978). A plate or flat rock is placed on the soil inside the cylinder for erosion prevention when adding the water. The cylinder is filled to the top, and clock time is recorded. Water is allowed to lower about $5-10 \mathrm{~cm}$. The decline is measured with a ruler, clock time is recorded, and the cylinder is filled back to the top. This procedure is repeated for about $6 \mathrm{~h}$ or until the accumulated infiltration has reached about $50 \mathrm{~cm}$, whichever comes first. The last decline $y_{n}$ is measured and clock time is recorded to obtain the time increment $\Delta t_{n}$ for $y_{n}$. A shovel is used to dig outside the cylinder to determine the distance $x$ of lateral wetting or divergence (Fig. 7). The infiltration rate $i_{n}$ inside the cylinder during the last water-level decline is calculated as $y_{n} / \Delta t_{n}$. Assuming vertical flow in the entire wetted zone, the corresponding downward flow rate, or flux $i_{w}$ in the wetted area below a cylinder of radius $r$, is then calculated as:

$i_{w}=\frac{i_{n} \pi r^{2}}{\pi(r+x)^{2}}$

where $x$ is the distance of lateral wetting from the cylinder wall (Fig. 7).

The depth $L$ of the wet front at the end of the test is calculated from the accumulated declines $y_{t}$ of the water level in the cylinder as:

$L=\frac{y_{t} \pi r^{2}}{n \pi(r+x)^{2}}$

where $n$ is the fillable porosity of the soil. The value of $n$ can be estimated from soil texture and initial water content. For example, $n$ is commonly about 0.3 for dry uniform soils, 0.2 for moderately moist soils, and 0.1 for relatively wet soils. Well-graded soils have lower values of $\mathrm{n}$ than uniform soils. The value of $L$ can also be determined by augering or digging down immediately after the test to see how deep the soil has been wetted. This method works best if the soil initially is fairly dry, so that a good contrast exists between wet and dry soil, and

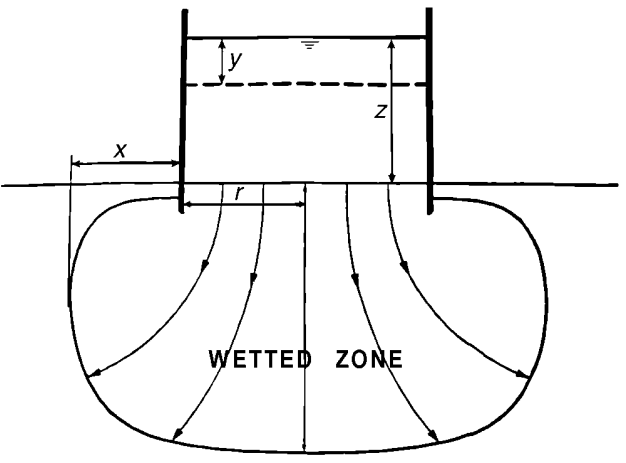

Fig. 7 Section showing geometry and symbols for single-ring infiltrometer

if not very many rocks are present. Applying Darcy's equation to the downward flow in the wetted zone then yields:

$i_{w}=\frac{K\left(z+L-h_{w e}\right)}{L}$

where $z$ is the average depth of water in the cylinder during the last water-level decline. The term $h_{w e}$ is the water-entry value of the soil and can be estimated from the data listed below Eq. (2). Because $K$ is now the only unknown in Eq. (5), it can be solved as:

$K=i_{w} L /\left(z+L-h_{w e}\right)$

This calculated value of $K$ is used as an estimate of longterm infiltration rates in large and shallow inundated areas, without clogging of the surface and without restricting layers deeper down. Because of entrapped air, $K$ of the wetted zone is less than $K$ at saturation, for example, about $0.5 \mathrm{~K}$ at saturation, as mentioned previously.

If the $K$ values calculated with Eq. (6) are sufficiently large for an infiltration system, the next step is to put in some test basins of about 0.2 ha for long-term flooding, to evaluate clogging effects and the potential for infiltration reduction by restricting layers deeper down, and to have confidence in the scaling up from essentially point measurements of infiltration rates with cylinders to fullscale projects that might have 10-100 ha of recharge basins. Good agreement has been obtained between predicted infiltration rates ( $K$ in Eq. 6) and those of larger basins. For example, six infiltrometers installed in a field west of Phoenix, Arizona, gave an average $K$ of $40 \mathrm{~cm} /$ day, as calculated with Eq. (6). Two test basins of 0.3 ha each in the same field yielded final infiltration rates of 30 and $35 \mathrm{~cm} /$ day (Bouwer et al. 1999b). If the infiltrometer tests give infiltration rates that are too low for surface-infiltration systems, alternative systems such as excavated basins, recharge trenches, recharge shafts or vadose-zone wells, or aquifer injection wells can be considered.

The cylinder infiltrometer procedure described above is by no means exact. However, in view of spatial variability (vertical as well as horizontal) of soil properties, 
exact procedures and measuring water-level declines with Vernier-equipped hook gages are not necessary. The main idea is to account somehow for divergence and limited depth of wetting, rather than applying a standard reduction percentage to go from short-term cylinder infiltration rates to long-term large-area infiltration rates, as has sometimes been done. Because of spatial variability, cylinder infiltration tests should be carried out at various locations within a given site. The resulting infiltration rates should never be expressed in more than two significant figures.

Where soils are stony, cylinder infiltrometers might be difficult to install. Sometimes, removing stones with a pick outside the cylinder as it is driven down and filling the empty spaces with a fine, powdery soil is possible. If not, alternative procedures are to use larger, bermed areas of at least $2 \times 2 \mathrm{~m}$ for infiltration measurement, or to take a disturbed sample of the soil material between the stones and measure its hydraulic conductivity in the laboratory. Void ratios of the soil alone and of the bulk stony soil mixture are then estimated or determined, so that $K_{b}$ of the stone-soil mixture is calculated with Eq. (1) to give an idea of basin infiltration rates (Bouwer and Rice 1984b).

\section{Soil Clogging}

The main problem in infiltration systems for artificial recharge of groundwater is clogging of the infiltrating surface (basin bottoms, walls of trenches and vadosezone wells, and well-aquifer interfaces in recharge wells), and resulting reduction in infiltration rates. Clogging is caused by physical, biological, and chemical processes (Baveye et al. 1998). Physical processes are accumulation of inorganic and organic suspended solids in the recharge water, such as clay and silt particles, algae cells, microorganism cells and fragments, and sludge flocs in sewage effluent. Another physical process is downward movement of fine particles in the soil that were in the applied water or in the soil itself, and accumulation of these fine particles at some depth where the soil is denser or finer, and where they form a thin subsurface clogging layer. The depth of this layer ranges from a few $\mathrm{mm}$ to a few $\mathrm{cm}$ or more. In the soils literature, this fine-particle movement and accumulation deeper down are called "wash out-wash in" (Sumner and Stewart 1992). Fine soil particles also form surface crusts when infiltration basins are dry and the soil is exposed to rainfall.

Biological clogging processes include:

1. accumulation of algae and bacterial flocs in the water on the infiltrating surface; and

2. growth of micro-organisms on and in the soil to form biofilms and biomass (including polysaccharides and other metabolic end products) that block pores and/or reduce pore sizes.

Chemical processes include precipitation of calcium carbonate, gypsum, phosphate, and other chemicals on and in the soil. Sometimes, these precipitations are induced by $\mathrm{pH}$ increases caused by algae as they remove dissolved $\mathrm{CO}_{2}$ from the water for photosynthesis. Bacteria also produce gases (nitrogen, methane) that block pores and accumulate below clogging layers to create vapor barriers to infiltration. Gas is also formed in soils below recharge basins or in trenches or wells when the recharge water contains entrained or dissolved air and/or is cooler than the soil or aquifer itself. The water then warms up in the soil or aquifer; air goes out of solution and forms entrapped air, which reduces the hydraulic conductivity. For well injection, this process is called air binding. Entrapped air also forms in response to decreases in water pressures, for example, when water moves through a clogging layer in a recharge basin and the pressure head is reduced from the water depth above the clogging layer to a negative pressure or suction in the unsaturated soil below the clogging layer. Well recharge also can cause precipitation of iron and manganese oxides or hydroxides as dissolved oxygen levels change, and to solution and precipitation of calcium carbonate due to changes in $\mathrm{pH}$ and dissolved carbon dioxide levels. Conversely, dissolution of calcite by injected water is known to increase hydraulic conductivity of limestone aquifers used for aquifer storage and recovery (Dillon and Pavelic 1996).

Because infiltration rates vary inversely with water viscosity, temperature also affects infiltration rates. In areas with large differences between winter and summer temperatures, viscosity effects alone cause winter infiltration rates to be as low as about half of those in summer. Thus, if recharge systems need to be based on a certain capacity, they should be designed on the basis of the winter conditions, when water is coldest and infiltration rates are lowest. On the other hand, biological activity and the clogging that it causes might be highest in the summer. All these effects are hard to predict and the best way to get adequate design and management information for a full-scale project is by installing a few pilot basins of at least about $20 \times 20 \mathrm{~m}$ and operating them for groundwater recharge for at least a year to measure seasonal effects.

Because clogging layers are much less permeable than the natural soil material, they reduce infiltration rates and become the controlling factor or "bottleneck" in the infiltration process (Fig. 8). When the infiltration rate in surface systems becomes less than the hydraulic conductivity of the soil below the clogging layer, this soil becomes unsaturated to a water content whereby the corresponding unsaturated hydraulic conductivity is numerically equal to the infiltration rate (Bouwer 1982). The resulting unsaturated downward flow is then entirely due to gravity with a hydraulic gradient of unity. The thickness of clogging layers can range from $1 \mathrm{~mm}$ or less (biofilms, thin clay and silt layers or "blankets") to several centimeters and decimeters or more for thicker sediment deposits. Because clogging layers are the rule rather than the exception, flow systems below surface infiltration systems are typically as shown in Fig. 8, for vadose zones without restricting layers that otherwise 


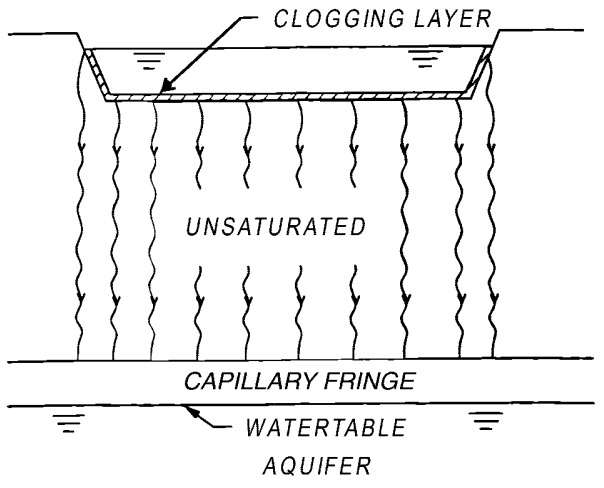

Fig. 8 Section showing infiltration basin with clogging layer, unsaturated flow to aquifer, and capillary fringe above water table

could cause perched water to rise too close to the basin bottom.

The infiltration rate $V_{i}$ for the basin in Fig. 8 can be calculated by applying Darcy's equation to the flow through the clogging layer:

$V_{i}=K_{c} \frac{H_{w}-h_{a e}}{L_{c}}$

where $K_{c}$ is the hydraulic conductivity of the clogging layer, $L_{c}$ the thickness of clogging in layer, $H_{w}$ the water depth above clogging layer, and $h_{a e}$ the air entry value of vadose-zone soil.

Because the clogging layer is often very thin, from less than $1 \mathrm{~mm}$ to about $1 \mathrm{~cm}$, its actual thickness and hydraulic conductivity are difficult to determine. For this reason, $K_{c}$ and $L_{c}$ are lumped into one parameter $L_{c} / K_{c}$, with the dimension of time (usually days) and called the hydraulic resistance $R_{c}$, which is the number of days it takes for a unit infiltration amount to move through the clogging layer at unit head loss. For a given system, $R_{c}$ is calculated with Eq. (7) from measured values of $V_{i}$ and head loss across the clogging layer, using a tensiometer to measure $h_{a e}$. Also, $h_{a e}$ is estimated as $2 h_{w e}$, using the values shown below Eq. (2). The air-entry value is more appropriate than the water-entry value in this case, because infiltration usually starts with a clean bottom condition, which causes the upper wetted zone initially to have positive water-pressure heads and, hence, to be near saturation. As the clogging develops and $V_{i}$ decreases, the wetted zone becomes increasingly unsaturated as water contents decrease to produce hydraulic conductivities numerically equal to infiltration rates. Thus, air is displacing water in this case, and the air-entry value is the more appropriate value to use for the pressure head below the clogging layer (Bouwer 1982). Air-entry and water-entry values are parameters in hysteresis-affected water-content characteristics. These are curves relating water content to (negative) water-pressure head. Because of hysteresis, they are different for drying and wetting of the soil (Bouwer 1978, and references therein).

Clogging is controlled by reducing the parameters that cause clogging. For surface water, this typically means pre-sedimentation to settle clay, silt, and other suspended solids. This effect is accomplished by dams in the river or aqueduct system (which would also regulate the flow) or by passing the water through dedicated presedimentation basins before recharge. Coagulants like alum and organic polymers are used to accelerate settling. For well recharge, sand or membrane filtration might also be necessary. Algae growth and other biological clogging in basins are reduced by removing nutrients (nitrogen and phosphorus) and organic carbon from the water. This reduction is also important where trenches, shafts, or wells are used for recharge with sewage effluent or effluent-contaminated water. Disinfection with chlorine or other disinfectants with residual effects reduces biological activity on and near the walls of the trenches, shafts, or wells and, hence, reduces clogging. Clogging rates increase with increasing infiltration rates, because of the increased loading rates of suspended solids, nutrients, and organic carbon on the surface. Because of this, increasing the injection pressures in recharge wells that show signs of clogging actually hastens the clogging process. Regular pumping of recharge wells and periodic redevelopment of the wells control and delay clogging, but possibly not "forever". Increasing the water depth in recharge basins or the injection pressure in recharge wells also compresses the clogging layer, which reduces its permeability and, hence, the infiltration rates (see section "Effect of water depth on infiltration"). Despite pretreatment of the recharge water, clogging still occurs due to growth of algae and autotrophic bacteria, dust being blown into the basin, and other factors.

For surface infiltration systems, clogging is also controlled by periodically drying the basins or other infiltration facility, thereby letting the clogging layer dry, decompose, shrink, crack, and curl up. This procedure is generally sufficient to restore infiltration rates to satisfactory values. If clogging materials continue to accumulate, they must be periodically removed at the end of a drying period. This removal is done mechanically with scrapers, front-end loaders, graders, or manually with rakes. After removal of the clogging material, the soil should be disked or harrowed to break up any crusting that might have developed at or near the surface. Disking or plowing clogging layers as such into the soil without first removing them gives short-term relief, but eventually fines and other clogging materials accumulate in the topsoil and the entire disk or plow layer must be removed. Disking or harrowing might have to be followed by smoothing and lightly compacting of the soil to prevent fine particle movement and accumulation of the fine particles on the underlying undisturbed soil when the soil is flooded again. This activity is done by rolling or by dragging a pole or other implement over the soil. For good quality surface water with very low suspendedsolids contents and coarse soil materials in the recharge basin, drying and cleaning might be necessary only a few times a year or even less frequently. Where soils are relatively fine-textured or have many stones, clogging control becomes a major challenge. Where the water is very 
muddy or where inadequately treated sewage effluent is used, drying and cleaning might be needed after each flooding period, which might then be as frequently as every few days.

Pre-sedimentation is especially important where recharge water is obtained from streams with variable flows and as much water as possible needs to be used for groundwater recharge. Maximum volumes of water then might need to be captured during periods of high flow. For this purpose, deeper-than-normal infiltration basins are constructed to capture and store as much flood flow as possible for subsequent infiltration and groundwater recharge. However, flood waters tend to carry a lot of sediment, which settles out in the deep basins. Because of particle segregation according to Stokes' law, the sediment layer then has its coarsest particles on the bottom and its finest particles on top. This arrangement greatly reduces infiltration rates, especially if there have been repeated inflows of muddy water into the basin. Such inflows tend to create multi-layered clogging layers on the bottom with particle-size segregation in each layer (Bouwer et al. 2001). Thus, the best way to utilize flood waters for artificial recharge is to capture and store these waters in deep basins or reservoirs that provide pre-sedimentation but are not expected to give high infiltration rates. Clear water is then taken out of these reservoirs and placed into infiltration basins that can be readily dried and cleaned to maintain high infiltration rates, and, hence, should be shallow (Bouwer and Rice 2001).

\section{Hydraulic Loading vs. Infiltration Rates}

Because of the need for regular drying and periodic cleaning of recharge basins or other surface infiltration systems, hydraulic capacities are best expressed in longterm average infiltration rates or hydraulic loading rates that take into account dry or "down" time. For example, if infiltrometers give an infiltration rate of $1 \mathrm{~m} /$ day and clogging causes infiltration rates of a basin to gradually decrease to $0.5 \mathrm{~m} /$ day after 2 weeks of flooding, and if then a drying period of 2 weeks is necessary to dry and clean the basin to restore the infiltration rate to its original value of $1 \mathrm{~m} / \mathrm{day}$, the basin would be dry half the time and have an average infiltration rate of $0.75 \mathrm{~m} /$ day during flooding. This value gives a long-term hydraulic loading rate of $182.5 \times 0.75=138 \mathrm{~m} /$ year or $0.37 \mathrm{~m} /$ day. At this rate, 1 ha can handle $3,700 \mathrm{~m}^{3} /$ day. Thus, if $10,000 \mathrm{~m}^{3} /$ day needs to be recharged, a basin area of 2.7 ha would be required. Seasonal effects also need to be considered, because hydraulic loading rates in winter are often less than in summer, due to cooler water with higher viscosity and to slower drying and infiltration recovery. On the other hand, biological activity and bioclogging might be more intense in the summer. This activity reduces infiltration rates. Infiltration and hydraulic loading rates are site-specific and are best evaluated on pilot basins or on actual systems. Schedules of flooding, drying, cleaning, and disking or other tillage for optimum hydraulic loading are developed by trial and error.
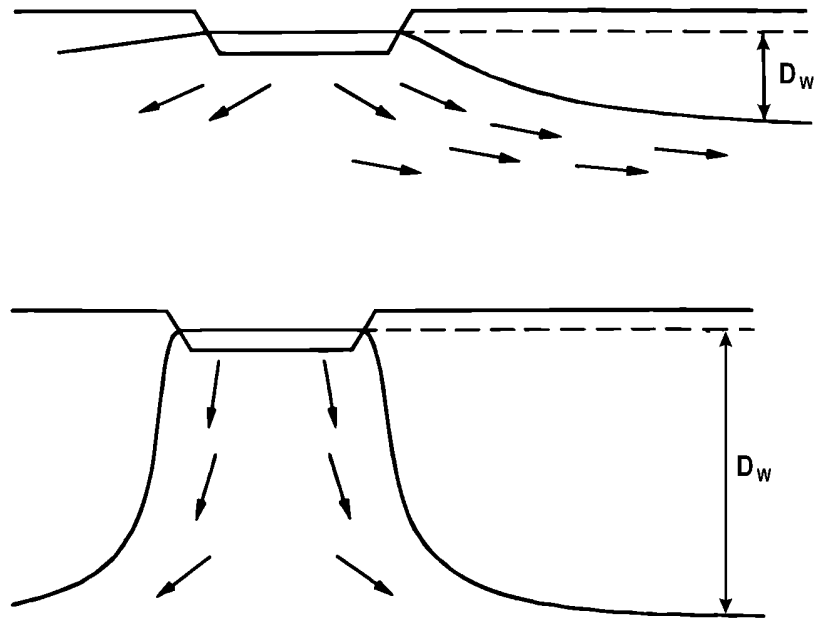

Fig. 9 Sections showing recharge basin with shallow water table and lateral flow in aquifer controlled by slope of water table (top), and with deep water table with downward flow below basin controlled by gravity (bottom)

Experienced operators know that different infiltration basins often show different clogging and infiltration behavior and different responses to drying and cleaning, even within the same project. For this reason, multi-basin recharge projects should be designed so that each basin is hydraulically independent and can be operated according to its best schedule. Hydraulic loading rates for systems in warm, relatively dry climates with good-quality input water and operated year round typically are about $30 \mathrm{~m} /$ year for fine textured soils like sandy loams, $100 \mathrm{~m} /$ year for loamy sands, $300 \mathrm{~m} / \mathrm{year}$ for medium clean sands, and $500 \mathrm{~m} / \mathrm{year}$ for coarse clean sands.

Because annual evaporation rates from wet soil surfaces and free water surfaces commonly range from about $0.4 \mathrm{~m} /$ year for cool, wet climates to $2.4 \mathrm{~m} /$ year for warm, dry climates, evaporation losses are quite small compared with hydraulic loading rates. This differential makes groundwater recharge attractive for storing water, including long-term storage or water banking, because evaporation of groundwater from an aquifer is essentially zero, unless it is within reach of tree or plant roots (Bouwer 1975, 1978).

\section{Effect of Water Depth on Infiltration}

If no clogging layer exists on the bottom of an infiltration basin and the basin is "clean," the water table would rise to the water level in the basin, and the water in the basin and in the aquifer would then be in direct hydraulic connection (Fig. 9). If the depth $D_{W}$ of the water table below the water level in the basin at some distance from the basin is relatively small (Fig. 9, top), the flow away from the basin would be mostly lateral and be controlled by the slope of the water table. On the other hand, if the water table is deep and $D_{W}$ is relatively large (Fig. 9 bottom), the flow from the basin would be mostly downward and controlled by gravity. Thus, if the water depth 
in the basin is increased, $D_{W}$ also would increase. The resulting effect on infiltration is then significant if $D_{W}$ is small, but negligible when $D_{W}$ is already large. For example, if $D_{W}$ in the system shown in Fig. 9 is $3 \mathrm{~m}$ and the water depth in the basin is increased by $1 \mathrm{~m}$, the infiltration flow would increase by $33 \%$. If, on the other hand, $D_{W}=30 \mathrm{~m}$, the same $1 \mathrm{~m}$ increase in the basin water depth would increase infiltration by only $3.3 \%$.

If the basin were clogged, the infiltration flow would be controlled by the clogging layer, and the vadose zone below the basin is unsaturated, as shown in Fig. 8 (Bouwer 1982). In that case, infiltration rates increase almost linearly with water depth, as indicated by Eq. (7), if nothing else changes. However, an increase in water depth compresses the clogging layer, which then becomes less permeable. In that case, infiltration rates do not increase linearly with water depth and sometimes actually decrease, as has been observed in practice (Bouwer and Rice 1989). This compression occurs because increasing the water depth in a basin with unsaturated flow below the clogging layer increases the intergranular pressure in the clogging layer, which leads to compression of the layer in accordance with soil-consolidation theory (Bouwer and Rice 1989). Compressible clogging layers, like organic (sludge, algae) deposits or loose clay or "mucky" layers, have greater compression and greater permeability reductions than less-compressible clogging materials, like silts or fine sands.

Secondary effects also aggravate clogging. For example, if the water depth were to increase without a corresponding increase in infiltration rate, the rate of turnover of the water in the basin would decrease. This effect causes suspended unicellular algae such as Carteria klebsii to be exposed to sunlight for longer periods, which increases their growth rate, and hence, increases the algal filter cake or clogging layer on the bottom as more algal cells are physically strained out by the soil. Also, a high algal concentration on the bottom and in the water increases the $\mathrm{pH}$ of the water due to uptake of dissolved $\mathrm{CO}_{2}$ for photosynthesis by the algae. This increase causes calcium carbonate to precipitate out and accumulate on the bottom, thus further aggravating the clogging problem and causing infiltration rates to decline even more. These processes explain why increasing water depths in infiltration basins to prevent infiltration reductions by clogging has actually caused further reductions in infiltration rates, to the surprise and dismay of operators who thought that providing more "head" on the clogging layer would overcome infiltration reductions by clogging layers. For this and other reasons, such as easier and quicker drying of basins for restoring infiltration rates, shallow recharge basins with water depths of about $0.5 \mathrm{~m}$ or less are generally preferred over deep basins.

\section{Effects of Artificial Recharge on Groundwater Levels}

Rises in groundwater levels below infiltration systems, or mounding, can occur in two ways, perched mounding
Fig. 10 Section showing geometry and symbols for infiltration system with perched groundwater above a restricting layer with hydraulic conductivity $K_{r}$

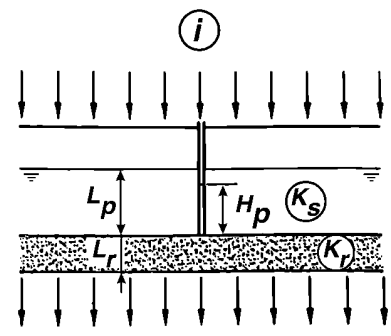

and aquifer mounding. If layers exist in the vadose zone whose hydraulic conductivity is less than the infiltration rate from the recharge basin, water accumulates above these "perching" layers to form "perched" groundwater. This perched groundwater then rises until it develops enough head on the perching layer for the flow to go through the perching layer at the same rate as that with which it arrives from above, and the perched water table reaches an equilibrium position. For large recharge areas, this process can be considered a one-dimensional flow system (Fig. 10). Applying Darcy's equation to the vertically downward flow in the perched groundwater above the restricting layer and through the restricting layer itself gives two equations with two unknowns (Bouwer et al. 1999b), which, when solved for the equilibrium height of the perched groundwater mound, yields:

$L_{p}=L_{r} \frac{\frac{V_{i}}{K_{r}}-1}{1-\frac{i}{K_{s}}}$

where $L_{p}$ is the equilibrium height of perched mound above restricting layer, $L_{r}$ the thickness of restricting layer, $V_{i}$ the infiltration rate and downward flux through soil and restricting layer, $K_{r}$ the hydraulic conductivity of restricting layer, and $K_{s}$ the hydraulic conductivity of soil above restricting layer.

Often, $V_{i}$ is much smaller than $K_{s}$ because surface soils tend to be finer textured than deeper soils, or a clogging layer is on the bottom of the infiltration system that reduces infiltration rates. Also, $V_{i}$ is often considerably larger than $K_{r}$. For these conditions, Eq. (8) can be simplified to:

$L_{p}=V_{i} \frac{L_{r}}{K_{r}}$

which is useful to see if perching could be a problem.

In stratified soils, perching layers commonly consist of discontinuous layers or lenses, which cause a circuitous downward flow. Also, for long, narrow recharge basins or recharge "strips", lateral spread of perching mounds above restricting layers (Bouwer 1962) is often significant. If so, the vertical fluxes are less and they cross the restricting layer over a larger area than that of the infiltration system. This condition also reduces the height of the perched mounds. In these circumstances, predicting the heights of perched groundwater mounds with Eqs (8) or (9) overestimates mound heights.

Numerous papers have been published on the rise of a groundwater mound on the aquifer in response to infiltration from a recharge system, and some also on the de- 
cline of the mound after infiltration has stopped (Glover 1964; Hantush 1967; Marino 1975a, 1975b; Warner et al. 1989). The usual assumption is a uniform isotropic aquifer of infinite extent with no other recharges or discharges. One of the difficulties in getting meaningful results from the equations is getting a representative value of aquifer transmissivity. The most reliable transmissivity data come from calibrated models. Next in reliability are values obtained from Theis-type pumping tests, step-drawdown, and other pumped-well tests; and slug tests (in decreasing order of "sampling" size). Slug tests (Butler 1997), although simple to carry out, always have the problem of how to get representative areal values from essentially point measurements (the usual scalingup problem). Averages from various tests often substantially underestimate more regional values (Bouwer 1996, and references therein). Also, results from slug tests on newly-drilled holes (sometimes intendend only for slug testing and future monitoring) are commonly influenced by residual drilling mud around the screened section of the well and, hence, underestimate the hydraulic conductivity. Piezometers at two different depths in the center of a mound enable the determination of both vertical and horizontal hydraulic conductivity of an aquifer already being recharged with an infiltration system, through model simulation (Bouwer et al. 1974).

In a deep or thick unconfined aquifer, streamlines of recharge flow systems are concentrated in the upper or "active" portion of the aquifer, with much less flow and almost stagnant water in the deeper or "passive" portion of the aquifer. Use of transmissivities of the entire aquifer between the water table and the impermeable lower boundary for mound calculations then seriously underestimates the rise of the mound. Older work (Bouwer 1962) with resistance-network analog modeling showed that for long rectangular recharge areas or recharge strips and a very thick aquifer, the thickness of the active, upper portion of the aquifer is about equal to the width of the recharge area. This thickness should then be multiplied by $K$ of the upper aquifer to get an "effective" transmissivity for mounding predictions. Also, if the Hantush or another equation is used to calculate longterm mound formation, as for water banking in areas with deep groundwater levels, larger transmissivity values should be used to reflect the increase in transmissivity as groundwater levels rise. Otherwise, the Hantush equation overestimates the mound rise.

The best way to get representative transmissivity values for artificial recharge systems is to have a large enough infiltration test area or pilot project that produces a groundwater mound, and then to calculate the transmissivity from the rise of that mound using, for example, the Hantush equation (Eq. 10). The fillable porosity to be used in the equations for mound rise is usually larger than the specific yield of the aquifer, because vadose zones often are relatively dry, especially in dry climates and if they consist of coarse materials like sands and gravels. The fillable porosity should be taken as the difference between existing and saturated water contents of
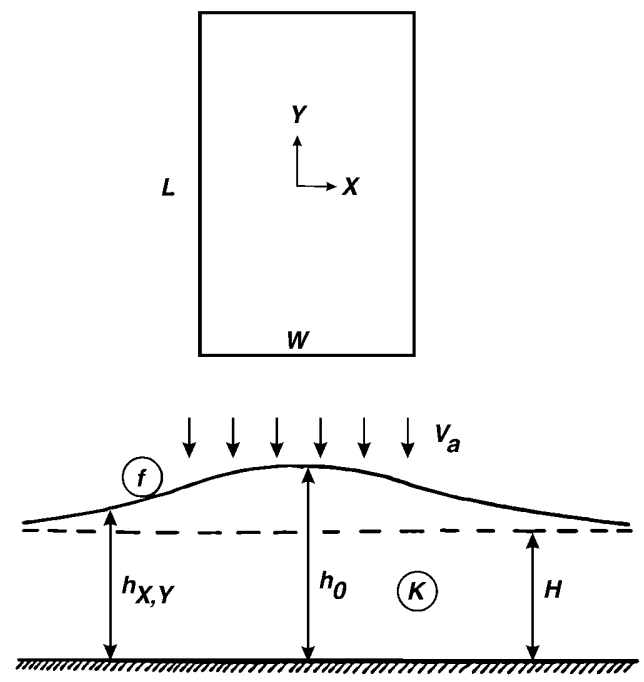

Fig. 11 Plan view (top) and section (bottom) of an infiltration and recharge system showing geometry and symbols for Hantush equation

the material outside the wetted zone below the infiltration system. The Hantush equation (Fig. 11) is:

$$
\begin{aligned}
h_{x, y, t}-H=\frac{V_{a} t}{4 f} & \{F[W / 2+x) n,(L / 2+y) n] \\
& +F[W / 2+x) n,(L / 2-y) n] \\
& +F[W / 2-x) n,(L / 2+y) n] \\
& +F[W / 2-x) n,(L / 2-y) n]\}
\end{aligned}
$$

where $h_{x, y, t}$ is the height of water table above impermeable layer at $x, y$, and time $t$ (Fig. 11), $\mathrm{H}$ the original height of water table above impermeable layer, $V_{a}$ the arrival rate at water table of water from infiltration basin or basins, $t$ the time since start of recharge, $f$ the fillable porosity $(1>f>0), L$ the length of recharge basin or recharge project area (in $y$ direction), and $W$ the width of recharge basin or recharge project area (in $x$ direction); $n=(4 \mathrm{t} \mathrm{T} / \mathrm{f})^{-1 / 2}$, and $\mathrm{F}(\alpha, \beta)=\int_{0}^{1} \operatorname{erf}\left(\alpha \tau^{-1 / 2}\right) \cdot \operatorname{erf}\left(\beta \tau^{-1 / 2}\right) \mathrm{d} \tau$, where $\alpha=(\mathrm{W} / 2+\mathrm{x}) \mathrm{n}$ or $(\mathrm{W} / 2-\mathrm{x}) \mathrm{n}$ and $\beta=(\mathrm{L} / 2+\mathrm{y}) \mathrm{n}$ or $(\mathrm{L} / 2-\mathrm{y}) \mathrm{n}$. Values of $\mathrm{F}(\mathrm{x}, \beta)$ were tabulated by Hantush. They are available as electronic supplementary material (http://dx.do.org/10.1007/s10040-001-0182-4).

Values of $V_{a}, L$, and $W$ should be selected as they occur at the water table. If extensive perching and lateral flow occur in the vadose zone, $V_{a}$ is less than the average infiltration rate of the recharge area, and $L$ and $W$ are larger than the actual dimensions of the infiltration system. Usually, however, $V_{a}$ is taken as the infiltration rate for the entire recharge area (taking into account "dry" areas between basins), and $L$ and $W$ are taken as the dimensions of the entire recharge project. The Hantush equation is also used to calculate mound rises farther away from the recharge area, up to distances of about $0.5 \mathrm{~W}$ and $0.5 \mathrm{~L}$, to avoid negative terms in the error function of Eq. (10). For predicting water-table effects farther away from the project, the Theis equation is used. Computer models like Modflow (McDonald and Harbaugh 1988) are used to include other regional recharge inputs and pumped-well outputs for the aquifer. 
Often of most interest to operators and managers is the long-term effect of recharge on groundwater. Appropriate questions include:

- where will the groundwater mound be 10,20 , or 50 years from now;

- how much water can be stored or "banked" underground;

- will the whole area become waterlogged; and

- how must the water be recovered from the aquifer to prevent waterlogging or undue water-level rises of the recharge area and adjacent areas?

Some water-banking projects have been installed or are planned in the desert valleys or basins of southern California and Arizona. Because these regions will then have basins for recharge and wells for pumping groundwater, an interest also exists to collect the natural recharge that is occurring in those areas, so that more water is pumped out of the aquifer than is put in with artificial recharge. This plan has sparked intensive interest in estimating natural recharge rates, which in these dry climates is very small (Tyler et al. 1996) and only a fraction (maybe about $1 \%$ ) of a very small precipitation (about $10 \mathrm{~cm} /$ year, or even less). To avoid depletion of the groundwater, excess pumping of groundwater should not exceed natural recharge rates. Monitoring is necessary to make sure that undesirable depletions or other groundwaterlevel responses do not occur.

A quick idea about ultimate or quasi-equilibrium mound heights for water banking or other recharge projects is obtained from a steady-state analysis, where the mound is considered to be in equilibrium with a constant water table at some depth and at a large distance from the infiltration system. The constant "far-away" water table can be established by groundwater pumping, discharge into surface water like rivers or lakes, or some other "control." Also, the farther away from the recharge area, the slower the water table rises. Thus, when groundwater levels are far enough away from the recharge area, they can be considered essentially stable.

Usually, recharge systems consist of several basins or other infiltration facilities. Steady-state equations were developed for two general geometries of the entire recharge area:

1. the basins form a long strip with a length of at least five times the width, so that after long times it still performs about the same as an infinitely long strip (Glover 1964); and

2. the basins are in a round, square, or irregular area that can be represented by an equivalent circular area (Bouwer et al. 1999b).

For the long strip (Fig. 12), the groundwater flow away from the strip is taken as linear horizontal flow (Dupuit-Forchheimer flow). Below the infiltration area, the lateral flow is assumed to increase linearly with distance from the center. The lateral flow is then assumed to be constant between the edge of the recharge system at distance $W / 2$ from the center and the constant-control

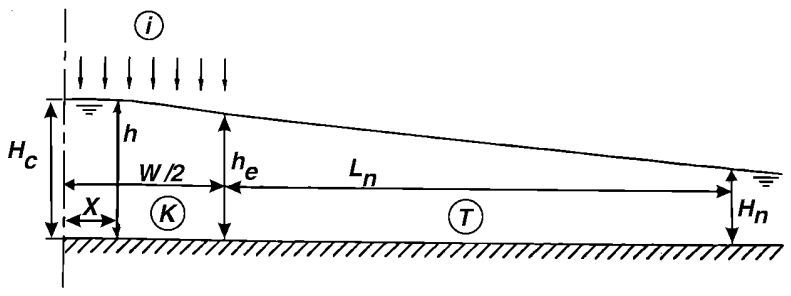

Fig. 12 Section showing geometry and symbols for groundwater mound below a long infiltration area (strip) of width $\mathrm{W}$

water table at distance $L_{n}$ from the edge (Fig. 12). This set of conditions yields the equation:

$H_{c}-H_{n}=\frac{i W}{2 T}\left(\frac{W}{4}+L_{n}\right)$

for the ultimate rise of the groundwater mound below the center of the recharge strip when equilibrium exists between recharge and pumping from the aquifer (Bouwer et al. 1999b). In this equation, $H_{c}$ is the height of groundwater mound in center of recharge area, $H_{n}$ the height of water table at control area, $i$ the average infiltration rate in recharge area (total recharge divided by total area), $W$ the width of recharge area, $L_{n}$ the distance between edge of recharge area and control area, and $T$ the transmissivity of aquifer (Fig. 12).

For a round or square type of recharge area (Fig. 13), the groundwater flow is radially away from the area. The equilibrium height of the mound below the center of the recharge system above the constant water table at distance $R_{n}$ from the center of the recharge system can be calculated with radial flow theory (Bouwer et al. 1999b) as:

$H_{c}-H_{n}=\frac{i R^{2}}{4 T}\left(1+2 \ln \frac{R_{n}}{R}\right)$

where $R$ is the radius or equivalent radius of the recharge area, $R_{n}$ is the distance from the center of the recharge area to the water-table control area (Fig. 13), and the other symbols are as previously defined.

Equations (11) and (12) are used to predict the final mound height below a recharge area for a given elevation of the control water table at distance $R_{n}$ or $L_{n}$ from the recharge area. As indicated for the Hantush equation, the value of $T$ in Eqs (11) and (12) must reflect the average transmissivity of the aquifer at the ultimate equilibrium mound height.

If the calculated ultimate mound height is too high, $R_{n}$ or $L_{n}$ must be reduced by groundwater pumping from wells closer to the recharge area, or $H_{n}$ must be reduced by pumping more groundwater. Equations (11) and (12) then indicate where groundwater should be recovered and to what depth groundwater levels should be pumped to prevent water tables below the recharge areas from rising too high. Ultimate mound heights can also be reduced by making the recharge area longer and narrower, or by reducing recharge rates by using less water for recharge or by spreading the infiltration facilities over a larger area. 


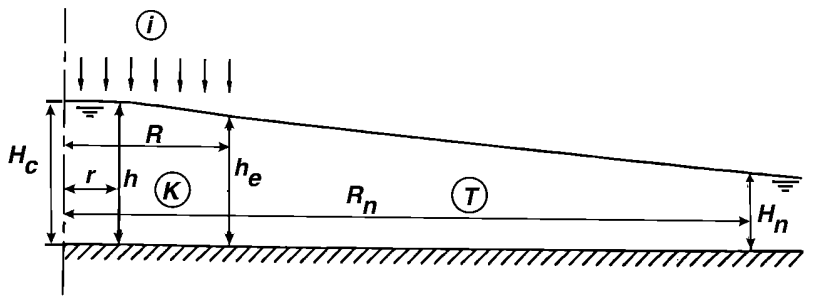

Fig. 13 Section showing geometry and symbols for groundwater mound below round infiltration area of radius $R$

\section{Effects of Groundwater Levels on Infiltration Rates}

Often, bottoms and banks of infiltration basins are covered with a clogging layer that controls and reduces infiltration rates so that the underlying soil material is unsaturated (Fig. 8). The water content in the unsaturated zone then establishes itself at a value whereby the corresponding unsaturated hydraulic conductivity is numerically equal to the infiltration rate, because the downward flow is due to gravity alone and the hydraulic gradient is unity (Bouwer 1982). The unsaturated zone breaks the hydraulic continuity between the basin and the aquifer, so that infiltration rates are independent of depth to groundwater, as long as the water table is deep enough that the top of the capillary fringe above the water table is below the bottom of the basin. This capillary fringe is commonly about $30 \mathrm{~cm}$ thick for medium sands, more for finer sands or soils, and less for coarse sands. Thus, a conservative conclusion is that as long as the water table is more than about $1 \mathrm{~m}$ below the bottom of a basin where infiltration is controlled by a clogging layer on the bottom, infiltration rates are unaffected by changes in groundwater levels. If the water table rises, infiltration rates start to decrease only when the capillary fringe reaches the bottom of the basin. They then continue to decrease linearly with decreasing depth to groundwater below the water level in the basin, until they become zero when the water table has risen to the same elevation as the water surface in the basin. The transition between hydraulically disconnected water-table conditions (Fig. 8) to hydraulic connection (Fig. 9) was modeled by Dillon and Liggett (1983), who observed that infiltration rates decline significantly due to hydraulic connection as a result of infiltration causing the water table to rise and intersect the basin or stream.

Where the water for recharge is exceptionally clear and free from nutrients and organic carbon, temperatures are low, and soils are relatively coarse, then infiltration proceeds for considerable time without development of a clogging layer on the bottom. In that case, direct hydraulic continuity exists between the clean basin and the aquifer with the water table joining the water surface in the basin (Fig. 9). Groundwater levels are then characterized by the depth $D_{W}$ of the water table below the watersurface elevation in the basin. $D_{W}$ should be taken at a sufficient distance from the recharge area such that groundwater levels are relatively unaffected by the recharge flow system (Fig. 9). In previous work, this dis-

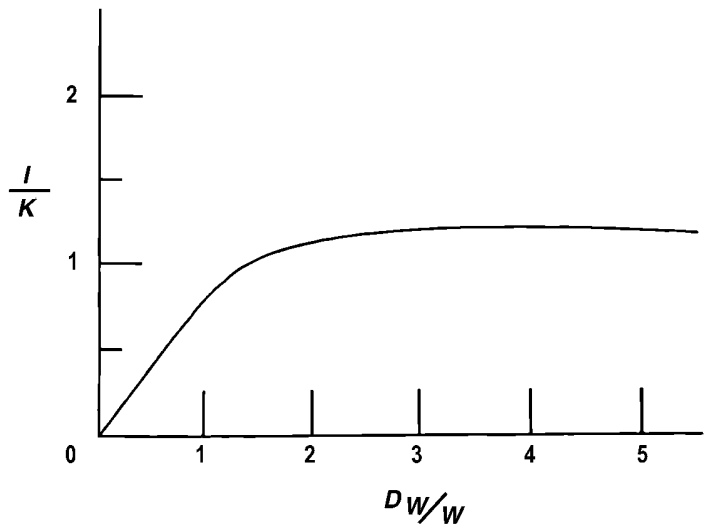

Fig. 14 Dimensionless plot of seepage (expressed as $I / K$ ) versus depth to groundwater (expressed as $D_{w} / W$ ) for clean stream channel or long infiltration basin with no clogging layer on bottom

tance was arbitrarily taken as ten times the width of the basin or recharge system (Bouwer 1969). If $D_{W}$ is relatively large, the flow below the recharge system is mainly downward and controlled by gravity (Bouwer 1969, 1978) so that the hydraulic gradient is about unity (Fig. 9, bottom). In that case, infiltration rates are essentially unaffected by depth to groundwater. However, if groundwater levels rise and $D_{W}$ decreases, the flow from the recharge basin becomes more and more lateral until eventually it is completely controlled by the slope of the water table away from the basin (Fig. 9, top; Bouwer 1969, 1978). Modeling these flow systems on an electrical-resistance network analog has shown that the change from gravity-controlled flow to flow controlled by slope of the water table occurs when $D_{W}$ is about twice the width $W$ (or diameter) of the recharge system (Bouwer 1990). This relationship is shown in Fig. 14, where $I$ is the infiltration rate per unit area of water surface in the basin and $K$ is the hydraulic conductivity in the wetted zone or aquifer. Thus, as long as $D_{W}<2 W$, infiltration rates decrease almost linearly with decreasing $D_{W}$ and reach zero when $D_{W}=0$ (Fig. 14). However, if $D_{W}>2 W$, infiltration rates are essentially constant and about equal to the theoretically maximum value when $D_{W}=\infty$, regardless of the actual value of $D_{w}$. These relationships apply to uniform, isotropic underground formations. Anisotropic or stratified situations need to be considered on a case-by-case basis. In the USA, legal aspects of groundwater and surface-water interactions do not always conform with hydrologic aspects (Bouwer and Maddock 1997).

Infiltration rates in clean basins (no clogging layers) thus are more sensitive to depth to groundwater than rates in clogged basins. Clogged basins are the rule rather than the exception, and groundwater mounds can rise much higher there than below clean basins before reductions in infiltration rates occur. Sometimes, maximum permissible mound heights are dictated by circumstances other than their effect on infiltration rates, such as presence of sanitary landfills, underground sewers or other 
pipelines, basements (especially deep basements of commercial buildings), cemeteries, and deep-rooted vegetation like old trees that die when groundwater levels rise too high.

\section{Vadose-Zone Wells}

Vadose-zone wells, also called dry wells or recharge shafts, are boreholes in the vadose zone, usually about 10-50 $\mathrm{m}$ deep and about 1-2 $\mathrm{m}$ in diameter (Fig. 3). They are commonly used for infiltration and "disposal" of storm runoff in areas of relatively low rainfall that have no storm sewers or combined sewers. Dry wells normally are drilled into permeable formations in the vadose zone that can accept the runoff water at sufficient rates. Where groundwater is deep (for example, 100$300 \mathrm{~m}$ or more), dry wells are much cheaper than recharge wells and, hence, it is tempting to use dry wells for groundwater recharge instead of aquifer wells. Such vadose-zone wells are similar to recharge pits or recharge shafts, which also have been used for recharge of groundwater. To get adequate recharge, vadose-zone wells should penetrate permeable formations for a sufficient depth. On the other hand, where recovery wells pump the water from the aquifer, the pumped wells could also be used for recharge, so that vadose-zone wells might not be necessary (see section on "Aquifer Storage and Recovery Wells"). Also, where groundwater levels are very deep and vadose zones relatively dry, considerable volumes of water are needed to wet the vadose zone before water arrives at the aquifer.

The main problem with vadose-zone wells is, of course, clogging of the wall of the well and the impossibility of remediating that clogging by pumping or redeveloping the vadose-zone well, because the well is in the vadose zone and groundwater cannot flow into it the well and "backwash" the clogging material. Also, energy-based cleaning techniques like surging and jetting cannot be used, because vadose-zone wells are filled with sand or gravel. Thus, clogging must be prevented or minimized. This goal is achieved by protecting the water in the well against slaking and sloughing of clay layers in the vadose zone that could make the water in the well muddy, causing clay to accumulate and form a clogging layer on the more permeable soil material, where most of the infiltration takes place. This slaking is minimized by filling the well with sand and using a perforated pipe or screen in the center to apply the water for recharge. Placing plastic sheets or geotextiles in the well against the zones with clay layers can also be effective. Also, the water must be treated before recharge to remove as many clogging agents as possible, including suspended solids, assimilable organic carbon, nutrients, and microorganisms. Disinfection to maintain a residual chlorine level is also helpful. If clogging still occurs (and long-term clogging is always a possibility), it is mostly due to bacterial cells and organic metabolic products like polymers on the wall of the well. Thus, whereas such clogging cannot be remedied by pumping, cleaning, or redevelopment, a very long drying period could result in sufficient biodegradation of the clogging material to restore the vadosezone well for another episode of recharge, albeit at reduced rates.

Because recharge with aquifer wells or vadose-zone wells is much more expensive than with surface infiltration systems, rigorous economic analyses are necessary to develop the best system. Factors to be considered include the cost of vadose-zone wells compared with aquifer wells, their recharge capacities and the number of wells needed, their useful lives, maintenance and/or replacement costs, and the cost of necessary pretreatment of the water. Contaminated vadose zones usually preclude the use of vadose-zone wells.

Recharge rates for vadose-zone wells in uniform soil materials are calculated from Zangar's equation for reverse auger-hole flow (Bouwer 1978). For a typical vadose-zone well geometry, with groundwater levels significantly below the bottom of the well and a water depth in the well of at least five well diameters, this equation can be simplified to:

$Q=\frac{2 \pi K L_{w}^{2}}{\ln \left(2 L_{w} / r_{w}\right)-1}$

where $Q$ is the recharge rate, $K$ is the hydraulic conductivity of the soil material, $L_{w}$ is the water depth in the well, and $r_{w}$ is the radius of the well (Fig. 3). $L_{w}$ should be at least $10 r_{w}$ for the equation to be valid. The proper value for $K$ is difficult to assess, because the wetted zone is not always saturated and the streamlines have horizontal and vertical components, which complicates matters for anisotropic soils. The best way to evaluate $K$ for use in Eq. (13) is from test wells in the vadose zone.

More research is needed on vadose-zone recharge wells to develop an optimum design for well capacity, clogging control (including pretreatment and superdisinfection), useful life, and minimum long-term cost of recharge per unit volume of water. Superdisinfection consists of maintaining such a high residual disinfectant level in the recharge water that microbiological activity cannot occur in the well itself but takes place farther away in the vadose zone or aquifer, where the disinfectant is dissipated and biological activity can occur. The expectation is that this activity would then be far enough away from the well so that it occurs over a large enough area to prevent development of a clogging zone. Instead, it could develop a biofilter zone, which could even improve the quality of the recharge water going through it. More research is necessary to see if this approach is possible and how it could be managed for optimum recharge capacity and water-quality improvement. Ultimately, the usefulness of vadose-zone wells or trenches depends on their useful lives and the cost of recharge per unit volume of water added to the aquifer.

\section{Seepage Trenches}

Where permeable surface soils are not available but permeable strata occur within trenchable depth (about 
2-5 m, for example), drilled vadose-zone wells are probably not necessary and seepage trenches (also called infiltration trenches) are likely to be more cost-effective (Fig. 3). The trenches are backfilled with coarse sand or fine gravel, water is applied to the surface of the backfill, and the trench is covered to keep out sunlight, animals, and people (Hantke 1983) and to make the trenches "invisible" by giving them the same surface condition as the surrounding area. Clogging is reduced by use of geotextiles on or in the backfill to filter the water and by placing plastic sheets against clay zones in the trench to prevent sloughing of the clay and mud from entering the trench. As with vadose-zone and aquifer wells, the water for seepage trenches must have a very low suspendedsolids content. Using a simple conversion from radial flow from a vertical line source to parallel flow from a vertical plane source, the recharge rate for seepage trenches is estimated to be about $20 \%$ of $Q$ calculated with Eq. (13) for a vadose-zone well. This recharge rate then applies to a trench width and length section equal to the diameter of the well (i.e., $2 r_{w}$ ) and a trench-water depth equal to the water depth in the well. Thus, if a dry well $1 \mathrm{~m}$ in diameter, $10 \mathrm{~m}$ deep, and filled with water to the top infiltrates $1,000 \mathrm{~m}^{3} / \mathrm{day}$, a tranch $10 \mathrm{~m}$ deep, $1 \mathrm{~m}$ wide, and full of water infiltrates about $200 \mathrm{~m}^{3} /$ day per meter length of trench. As with surface infiltration systems, experimental vadose-zone wells or trenches should always be installed in new areas where there is no previous experience with these systems, to see how they perform and how they should be designed and managed (including pre-treatment of the water) for optimum performance in a full-scale system.

\section{Wells}

To predict the clogging potential of the water for well injection, three main clogging parameters are identified (Peters and Castell-Exner 1993): the membrane filtration index (MFI), the assimilable organic carbon content (AOC), and the parallel filter index (PFI). These parameters can also be used for evaluating water for vadosezone wells and trenches. The MFI describes the suspended-solids content of the water in terms of the slope of the straight portion of a plot of time/volume versus volume in a membrane filter test, using, for example, a $0.45-\mu \mathrm{m}$ Millipore filter. Thus, the dimensions of the MFI are time/volume ${ }^{2}$, for example, $s / 1^{2}$.

AOC is determined microbiologically by plating out and incubating a water sample for growth of bacteria of the type Pseudomonas fluorescence, counting the bacterial colonies, and expressing the results in terms of the carbon concentration of an acetate solution producing the same bacterial growth. AOC can be less than $1 \%$ of dissolved organic carbon (DOC). AOC levels in the recharge water should be below $10 \mu \mathrm{g} / \mathrm{l}$ to avoid serious clogging of the well if no chlorine is added to the water. If a residual chlorine level is maintained before recharge, higher AOC levels are probably tolerable. Rather than AOC, biodegradable organic carbon or BDOC is often preferable as a biological clogging parameter, especially for higher organic carbon concentrations. BDOC is easier to determine than AOC, because BDOC is based on degradation of organic carbon by passing the water through laboratory soil columns or in batch tests with soil slurries.

The PFI is determined by passing the recharge water through columns filled with the appropriate aquifer material. The flow rates per unit area through the columns are then maintained at much higher values than the infiltration rates per unit area of the aquifer around the well. Thus, clogging occurs faster in the columns than in the well, and the PFI serves as an early warning of clogging to come for the recharge well so that preventive or remedial action can be taken early.

Experience has shown that MFI, AOC, and PFI are useful parameters for comparing relative clogging potentials of various waters, but that they cannot be used to predict clogging and declines in injection rates for actual recharge wells, which also depend on well construction and aquifer characteristics. Thus full-scale studies on recharge test wells are still necessary to determine feasibility and design and management criteria for operational recharge wells. Practical aspects such as a varying flow in the water-supply pipes to the recharge project and associated possibility of fluctuating suspended-solids contents in the water also play a major role in well clogging. The suspended-solids fluctuations can be caused by formation of biofilms in the pipelines during periods of low flow, and by erosion of the biofilms during high flow. Treatment of the water at the recharge site to remove suspended solids before well injection might then be necessary.

Increasing injection pressures to overcome clogging effects is generally not successful and often actually hastens the clogging process by compressing the clogging layer in the same way as discussed in the section "Effect of Water Depth on Infiltration." Even if the clogging layer is not compressed by the higher injection pressures and if injection rates are indeed increased, the higher infiltration rates in the well then increase production of pore-clogging biomass, owing to higher loading rates of nutrients and organic carbon. They also increase physical clogging by higher loading rates of suspended solids. Increased injection rates by increasing injection pressures often are relatively short lived.

\section{Aquifer Storage and Recovery (ASR) Wells}

A relatively new and rapidly-spreading practice in artificial recharge is the use of ASR wells (Pyne 1995), which are a combination of recharge and pumped wells. They are used for recharge when surplus water is available and for pumping when the water is needed. ASR wells typically are used for seasonal storage of finished drinking water with a residual chlorine level in areas where water demands are much greater in summer than in winter, or vice versa, and where surface storage of water is not possible or is too expensive. The winter surplus is then 
stored underground with ASR wells, which are pumped in summer (or vice versa) to augment production from the water-treatment plant. The only treatment of the water pumped from the wells is chlorination. ASR wells make it possible to design and operate water-treatment plants for mean daily demand. The use of ASR wells to store seasonal surplus water and meet seasonal peak demands is often cheaper than the use of treatment plants and surface reservoirs with capacities based on peak demands without ASR wells. ASR wells are also used to store good-quality raw water supplies when they are in surplus and to pump them up to the water treatment plant when a need exists for that water. This capability is of special importance in parts of Europe, Australia, and other countries where people demand groundwater but where groundwater levels are depleted in the summer and must be replenished in the winter when there is more streamflow.

\section{Role of Recharge in Water Reuse}

Planned water reuse is expected to become increasingly important, not only in water-short areas where sewage effluent is an important water resource, but also where streams or other surface waters (including seawater at popular beaches) need to be protected (Bouwer 1993, 2000a). Sewage treatment for planned water reuse is often cheaper than the treatment for discharge into surface water that is necessary to protect in-stream and downstream users of that water against unacceptable pollution. Planned water reuse requires treatment of the effluent so that it meets the quality requirements for the intended reuse. Because of treatment costs, economic feasibility, and aesthetics, the treated sewage effluent is usually used for non-potable purposes, such as agricultural and urban irrigation (golf courses, sports fields, recreational and decorative lakes), power-plant cooling, industrial processing, construction, dust control, fire protection, toilet flushing (mostly in commercial buildings but also more and more in private homes), and environmental purposes (wetlands, riparian habitats, perennial streams, wildlife refuges). Unplanned or incidental use of sewage effluent for drinking or public water supplies goes on all over the world as municipalities share the same river for drinking water and sewage disposal (Crook et al. 1999).

Planned reuse for potable purposes is still rare but is expected to increase in the future (National Research Council 1994; McEwen and Richardson 1996; Crook et al. 1999). Water reuse and recycling also will probably be an important aspect of demand management in integrated water management (Bouwer 2000a). Inclusion of a groundwater recharge and recovery cycle in the reuse process has several advantages, such as storage to absorb seasonal or longer-term differences between supply of effluent and demand for reclaimed water, quality improvement of the effluent water as it moves or filters through soils and aquifers (soil-aquifer treatment or geo- purification), favorable economics, aesthetic benefits, and better public acceptance of water reuse. The latter is especially important for potable reuse, where the recharge cycle breaks up the undesirable pipe-to-pipe or toilet-to-tap connection that has been the bane of several proposed potable-water reuse schemes (Crook et al. 1999). Recharge and soil-aquifer treatment also make water reuse more acceptable in countries where a religious taboo exists against the use of "unclean" water (Ishaq and Khan 1997; Warner 2000).

If the recharge is via basins or other surface infiltration facilities, the sewage effluent is typically first given primary and secondary treatment, and disinfection with chlorine (National Research Council 1994). Primary effluent can also be used (Lance et al. 1980; Carlson et al. 1982; Rice and Bouwer 1984), and some projects use tertiary effluent, where the sewage after secondary treatment is filtered through sand or other granular medium and then chlorinated or otherwise disinfected. Primary treatment is a mechanical process that removes everything that floats or sinks. Secondary treatment is a biological process where bacteria degrade organic compounds in aerated tanks (activated sludge process) or trickling filters. Tertiary treatment consists of sand filtration and disinfection; and advanced treatment refers to all other treatment steps, such as lime precipitation; nitrification-denitrification; activated carbon filtration; and membrane filtration, such as reverse osmosis.

Often, water-quality improvement is the main objective of recharge with sewage effluent. For this reason, the systems are usually no longer called recharge systems, but soil-aquifer-treatment (SAT) systems or geopurification systems (Bouwer and Rice 1984a). SAT typically removes essentially all the suspended solids and micro-organisms (viruses, bacteria, protozoa like giardia and cryptosporidium, and helminth eggs). Nitrogen concentrations are greatly reduced by denitrification and possibly also by the recently-discovered process of anaerobic oxidation of ammonia (anammox; Van de Graaf et al. 1995; Kuenen and Jetten 2001). Dissolved organic carbon also is greatly reduced, typically from a range of 10-20 to $2-5 \mathrm{mg} / \mathrm{l}$. Most phosphates and metals are also removed from the water, especially in calcareous soils, but they accumulate in the underground environment (Bouwer and Rice 1984a).

Recovery wells for pumping water after SAT from the aquifer can be located so that they pump $100 \%$ reclaimed water (Fig. 15, top) and prevent the spread of reclaimed water into the natural groundwater outside the portion of the aquifer dedicated to SAT. Alternatively, the wells can be located to pump a mixture of reclaimed water and natural groundwater (Fig. 15, bottom). Water from wells such as shown in Fig. 15 is essentially pathogen-free and, hence, can be used as such for essentially all non-potable purposes, such as irrigation of lettuce and other crops consumed raw, parks, playgrounds, golf courses, fire protection, toilet flushing, etc. The main reason that this water cannot be used for drinking as such is the presence of residual organic carbon, which 
consists of a broad spectrum of mostly synthetic organic chemicals (E.J. Bouwer et al. 1984), some of which are carcinogenic or might have other adverse health effects. To protect the public health, California has set an upper limit of $1 \mathrm{mg} / \mathrm{l}$ for the total organic carbon (TOC) content of the water after SAT that is due to the sewage effluent. This distinction is made because some natural groundwaters actually have natural TOC contents of more than $1 \mathrm{mg} / \mathrm{l}$, due to humic and fulvic acids or other "natural" organic compounds. To keep the sewagederived TOC in the well water from systems like those shown in Fig. 15 to less than $1 \mathrm{mg} / \mathrm{l}$, the effluent can be treated by reverse osmosis or carbon filtration in the sewage treatment plant before groundwater recharge in
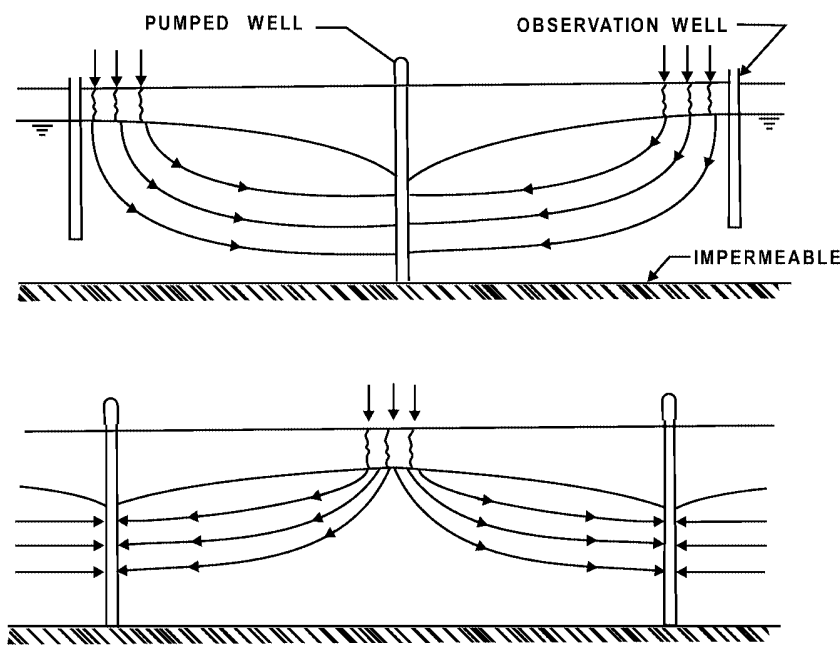

Fig. 15 Sections showing recharge and recovery SAT systems with infiltration areas (vertical arrows) in two parallel rows and line of wells midway in between (top), and in center area surrounded by a circle of wells or in a long strip with wells on both sides (bottom) systems as in Fig. 15. Another solution is to use systems as in Fig. 15 (bottom) with enough blending with natural groundwater that enters the wells from the opposite side of the infiltration area or from greater depth, to reduce the sewage TOC in the well water by dilution to less than $1 \mathrm{mg} / \mathrm{l}$. To achieve this, California has developed guidelines for potable use of water from wells in aquifers that are recharged with sewage effluent, as shown in Table 1. These guidelines and the percentages of reclaimed water in the well water are based on TOC removal in the SAT system to keep the well-water TOC of sewage origin below $1 \mathrm{mg} / \mathrm{l}$. Results from two major health-effects studies on morbidity and mortality in populations receiving water from systems as in Fig. 15 (bottom) in their public water supply indicate no adverse health effects (Nellor et al. 1984; Sloss et al. 1996). An emerging concern is the possibility that the sewage-effluent TOC also includes pharmaceuticals and hormones or hormonally active compounds (endocrine disrupters) whose underground fate and health significance are currently poorly understood (Daughton and Jones-Lepp 2001).

Another form of groundwater recharge with sewage effluent is the incidental recharge obtained where sewage effluent is used for irrigation. Because the treatment requirements for irrigation reuse are not as strict as for potable reuse, irrigation is likely to become an increasingly significant user of sewage effluent, especially in dry climates, where irrigation is essential for agricultural production and urban green areas (landscaping, recreational and athletic areas, private yards, etc.). For sustainable irrigation, the salts and other chemicals in the irrigation water must not be allowed to accumulate in the root zone of the crops or plants, but must be leached out of the root zone with natural rainfall as, for example, with the winter rains in Mediterranean-type climates, or with extra irrigation water where natural rain

Table 1 Proposed California guidelines for potable use of groundwater from aquifers recharged with sewage effluent (adapted from Crook et al. 2000 and California State Department of Health Services 2000; see also Asano and Levine 1998)

Contaminant type

Type of recharge

Surface spreading

$\mathrm{SS} \leq 30 \mathrm{mg} / 1$

$\leq 2 \mathrm{NTU}$

4-log virus inactivation, $\leq 2.2$ total coliform per $100 \mathrm{ml}$

6 months

$150 \mathrm{~m}$

Meet all drinking water MCLs

12 months

Retention time underground

Horizontal separation

Regulated contaminants

Unregulated contaminants

Secondary treatment

Reverse osmosis

Spreading criteria for SAT 50\% TOC removal credit

Mound monitoring option

Reclaimed water contribution in well water (RWC)

BOD $\leq 30 \mathrm{mg} / \mathrm{l}$, TOC $\leq 16 \mathrm{mg} / \mathrm{l}$

$\leq 1 \mathrm{mg} / \mathrm{l}$ TOC of waste-water origin at

drinking-water well

Depth to groundwater at initial percolation rate of:

$<0.5 \mathrm{~cm} / \mathrm{min}=3 \mathrm{~m},<0.7 \mathrm{~cm} / \mathrm{min}=6 \mathrm{~m}$

Demonstrate feasibility of the mound

compliance point

$600 \mathrm{~m}$

$\leq 50 \%$
$100 \%$ treatment to TOC $\leq 1 \mathrm{mg} / \mathrm{l} / \mathrm{RWC}$ NA

NA 
is insufficient. The amount of extra irrigation water needed for leaching is controlled by the salts in the irrigation water and the salt tolerance of the plants (Tanji 1990). Typically, the leaching requirement is about $10 \%$ of the irrigation amount needed for crop consumptive use (evaporation from the soil plus transpiration from the plant, or evapotranspiration, ET). This requirement corresponds to an irrigation efficiency of about $90 \%$, meaning that of the water applied, $90 \%$ is used for ET and $10 \%$ for leaching salts and other chemicals out of the root zone. Such high irrigation efficiencies can be achieved with sprinkler or drip systems. Most agricultural irrigation systems use flooding methods like borders or furrows, which have lower irrigation efficiencies, often about $50-80 \%$. This method leaves sufficient water for leaching and maintaining salt and chemical balances in the root zone. Irrigation efficiencies of $100 \%$ theoretically would only be sustainable without rainfall if distilled water were used for irrigation.

At an irrigation efficiency of $80 \%$, chemicals brought in with the irrigation water are leached out with $20 \%$ of the irrigation water. Thus, concentrations of salts and other chemicals not taken up by the plants or biodegraded or immobilized in the soil profile are five times higher in the leachate than in the irrigation water. This leachate, also called drainage or deep percolation water, then moves down to the groundwater, where in the long term it is likely to cause serious quality degradations (Bouwer 2000b; Lemly 1993). For example, assume that a 6-month summer crop in a warm, dry climate needs $1 \mathrm{~m}$ water for ET. At an irrigation efficiency of $80 \%$, the irrigation amount thus must be $1.25 \mathrm{~m}$ for the growing season, of which $0.25 \mathrm{~m}$ leaches through the root zone and moves to underlying groundwater. Assuming a water content of $15 \%$ in the vadose zone, the actual downward velocity of the water is about $0.25 / 0.15=$ $1.7 \mathrm{~m}$ per 6 months (assuming no movement in the rest of the year). Thus, if the groundwater is at a depth of $30 \mathrm{~m}$, it would take the water about $30 / 0.85=35$ years to move to the groundwater. Assuming a fillable porosity of $10 \%$ and vertical stacking of the deep percolation water above the groundwater, this deep percolation water adds a layer of $2.5 \mathrm{~m}$ per year of low-quality water to the aquifer. If the irrigation water has a salt content of $500 \mathrm{mg} / \mathrm{l}$, the deep percolation water would have a salt content of 2,500 mg/l. Significant rainfall would, of course, reduce this figure, which assumes no deep percolation from rainfall. If sewage effluent is used for irrigation, other chemicals in the leachate might include disinfection byproducts; natural and synthetic organic compounds like pharmaceuticals, hormones, and others (Lim et al. 2000); nitrate; and humic and fulvic acids that were already in the sewage effluent, plus those that were formed by decaying plant materials. These humic and fulvic acids could then form disinfection byproducts when the groundwater is pumped up again and chlorinated for drinking. Eventually, membrane filtration like reverse osmosis might have to be used to lower the salt concentrations in the upper groundwater to drinking-water levels. Membrane filtration would also remove other contaminants like nitrate, pharmaceuticals, and other synthetic organic compounds.

Because of this incidental recharge, irrigation with sewage effluent thus causes worse contamination of aquifers in the long run than artificial recharge with sewage effluent. In the latter case, hydraulic loading rates are much higher than evaporation rates and, hence, essentially no increases in chemical concentrations occur in the water moving down to the groundwater. Where land above potable aquifers is irrigated with sewage effluent, water and salt balances should be evaluated to predict possible long-term groundwater impacts. Groundwater monitoring might be necessary to see what actual effects such irrigation will have on underlying groundwater to determine what should be done to avoid or minimize adverse effects.

\section{Conclusions}

Artificial recharge of groundwater is expected to increase worldwide as populations rise. Factors affecting the availability of water resources include increasing demands for water while water resources remain finite; potential climate changes; lack of availability of good dam sites for surface storage; and increasing difficulty of building dams because of social, environmental, costs, and other objections. Also, dams are not effective for long-term storage of water because of evaporation losses. Artificial recharge, resulting in conjunctive use of surface water and groundwater and long-term underground storage or water banking, is preferred where possible. Artificial recharge also plays an important role in water reuse, because it gives quality benefits (soil-aquifer treatment) and storage opportunities to absorb seasonal differences between supply and demand for reclaimed sewage effluent. Where sewage effluent is used for potable purposes, recharge and recovery breaks the objectionable toilet-to-tap connection of water reuse and enables blending with natural groundwater. This enhances the aesthetics and public acceptance of potable-water reuse. Water reuse and storage of surplus water for use in times of water shortage also must be increasingly relied upon to cope with future uncertainties in climates and their effect on surface and groundwater supplies.

Design and management of artificial recharge systems involves geological, geochemical, hydrological, biological, and engineering aspects. Because soils and underground formations are inherently heterogeneous, planning, design, and construction of groundwater recharge schemes must be piecemeal, first testing for fatal flaws and general feasibility and then proceeding with pilot and small-scale systems until the complete system can be designed and constructed. This approach is especially valid for large systems, where scale effects are usually very significant and large amounts of money are commonly involved. 


\section{References}

Abu-Zreig M, Attom M, Hamasha N (2000) Rainfall harvesting using sand ditches in Jordan. Agric Water Manage 46(2):183192

Asano T (ed) (1985) Artificial recharge of groundwater, section III, Groundwater recharge operations. Butterworth, London, pp 357-576

Asano T, Levine AD (1998) Wastewater reclamation, recycling, and reuse: an introduction. In: Asano $\mathrm{T}$ (ed) Wastewater reclamation and reuse. Technomic, Lancaster, Pennsylvania, p 1-56

Baveye P, Vandevivere P, Hoyle BL, DeLeo PC, Sanchez de Lozada D (1998) Environmental impact and mechanisms of the biological clogging of saturated soils and aquifer materials. Crit Rev Environ Sci Technol, CRC Press 28(2):123-191

Bouwer H (1962) Analyzing groundwater mounds by resistance network, Journal Irrigation and Drainage Division, Am Soc Civil Eng 88 (IR 3):15-36

Bouwer H (1969) Theory of seepage from open channels. In: Chow VT (ed) Advances in hydroscience. Academic Press, New York, pp 121-170

Bouwer H (1975) Predicting reduction in water losses from open channels by phreatophyte control. Water Resour Res 11:96101

Bouwer H (1978) Groundwater hydrology. McGraw-Hill, New York, $480 \mathrm{pp}$

Bouwer H (1982) Design considerations for earth linings for seepage control. Ground Water 20(5):531-537

Bouwer H (1986) Intake rate: cylinder infiltrometer, In: Klute A (ed) Methods of soil analyses, Part 1 . Physical and mineralogical methods. Agronomy Monograph, 2nd edn, pp 825-844

Bouwer H (1989) Estimating and enhancing groundwater recharge. In: Sharma ML (ed) Groundwater recharge. Balkema, Rotterdam, pp 1-10

Bouwer H (1990) Effect of water depth and groundwater table on infiltration for recharge basins. In: Harris SC (ed) Proc 1990 Nat Conf Irrig Drain Div, Am Soc Civ Eng, Durango, Colorado, 11-13 July 1990, pp 337-384

Bouwer H (1993) From sewage farm to zero discharge. Eur Water Pollut Contr 3(1):9-16

Bouwer H (1996) Discussion of Bouwer and Rice slug test review articles. Ground Water 34:171

Bouwer H (1999) Artificial recharge of groundwater: systems, design, and management. In: Mays LW (ed) Hydraulic design handbook. McGraw-Hill, New York, pp 24.1-24.44

Bouwer H (2000a) Integrated water management, J Agric Water Manage 45:217-228

Bouwer H (2000b) Groundwater problems caused by irrigation with sewage effluent. J Environ Health 63(5):17-20

Bouwer H (2000c) The recharge of groundwater. Proc Natural Recharge of Groundwater Symp, Tempe, Arizona, USA, 2 June 2000, Arizona Hydrol Soc, pp 89-95

Bouwer H, Maddock T (1997) Making sense of the interactions between groundwater and streamflow: lessons for water masters and adjudicators. Rivers 6(1):19-31

Bouwer H, Rice RC (1984a) Renovation of wastewater at the 23rd Avenue rapid-infiltration project, Phoenix, Arizona. J Water Pollut Contr Fed 56(1):76-83

Bouwer H, Rice RC (1984b) Hydraulic properties of stony vadose zones. Ground Water 22(6):696-705

Bouwer H, Rice RC (1989) Effect of water depth in groundwater recharge basins on infiltration rate. J Irrig Drain Div, Am Soc Civil Eng 115(4):556-568

Bouwer H, Rice RC (2001) Capturing flood waters for artificial recharge of groundwater. Proc 10th Biennial Symp Artificial Recharge of Groundwater, Tucson, Arizona, Arizona Hydrological Society, pp 99-106

Bouwer H, Rice RC, Escarcega ED (1974) High-rate land treatment: I. Infiltration and hydraulic aspects of the Flushing Meadows Project, J Water Pollut Contr Fed 46(5):835843
Bouwer EJ, McCarty PL, Bouwer H, Rice RC (1984) Organic contaminant behavior during rapid infiltration of secondary wastewater at the Phoenix 23rd Avenue Project. Water Res 18:463-472

Bouwer H, Fox P, Westerhoff P, Drewes JE (1999a) Integrating water management and reuse: causes for concern? Water Qual Int, January-February, pp 19-22

Bouwer H, Back JT, Oliver JM (1999b) Predicting infiltration and ground water mounding for artificial recharge. J Hydrol Eng, Am Soc Civil Eng 4(4):350-357

Bouwer H, Ludke J, Rice RC (2001) Sealing pond bottoms with muddy water. J Ecol Eng 18(2):233-238

Butler JJ Jr (1997) The design, performance, and analysis of slug tests. Lewis Publishers, Boca Raton, Florida

California State Department of Health Services (2000) Water recycling criteria, title 22. Sacramento, California

Carlson RD, Lindstedt KD, Bennett ER, Hartman RB (1982) Rapid infiltration treatment of primary and secondary effluents. J Water Pollut Contr Fed 54:270-280

Crook J, MacDonald JA, Trussell RR (1999) Potable use of reclaimed water. J Am Water Works Assoc 91(8):40-49

Crook J, Hultquist R, Sakaji R (2000) New and improved draft groundwater recharge criteria in California. Proc Annu Conf Am Water Works Assoc (AWWA), Denver, Colorado

Daughton CG, Jones-Lepp T (eds) (2001) Pharmaceuticals and personal care products in the environment: scientific and regulatory issues. Symp Ser 791, Am Chem Soc, Washington, DC

Devine RS (1995) The trouble with dams. Atlantic Monthly, August 1995, pp 67-73

Dillon PJ, Liggett JA (1983) An ephemeral stream-aquifer interaction model. Water Resour Res 19(3):621-626

Dillon P, Pavelic P (1996) Guidelines on the quality of stormwater and treated wastewater for injection into aquifers for storage and reuse. Research Report No 109, Urban Water Research Association of Australia, Water Services Association of Australia, Melbourne

Dillon P, Pavelic P, Sibenaler X, Gerges N, Clark R (1997) Aquifer storage and recovery of stormwater runoff. Aust Water Wastewater Assoc J Water 24(4):7-11

Glover RE (1964) Ground water movement. US Bureau of Reclamation, Eng Monogr 31, 67 pp

Green WH, Ampt GA (1911) Studies on soil physics, I. The flow of air and water through soils. J Agric Sci 4:1-24

Hantke H (1983) Der Sickerschlitzgraben. Brunnenbau, Bau von Wasserwerken, und Rohrleitungsbau (BBR) 34(6):207-208

Hantush MS (1967) Growth and decay of ground water mounds in response to uniform percolation. Water Resour Res 3:227-234

Ishaq AM, Khan AA (1997) Recharge of aquifers with reclaimed wastewater: a case for Saudi Arabia. Arabian J Sci Eng 22(1C):133-141

Knoppers R, van Hulst W (1995) De Keerzijde van de Dam. Jan van Arkel. Utrecht, The Netherlands, $142 \mathrm{pp}$

Kuenen JG, Jetten MSM (2001) Extraordinary anaerobic ammonium-oxidizing bacteria. Am Soc Microb News 67(9):456-463

Kühn W (1999) Overview of riverbank filtration issues. Proc Int Riverbank Filtration Conf, Louisville, Kentucky, USA, sponsored by Nat Water Res Inst, Fountain Valley, California, USA, pp 1-4

Lance JC, Rice RC, Gilbert RG (1980) Renovation of sewage water by soil columns flooded with primary effluent. J Water Pollut Contr Fed 52(2):381-388

Lemly AD (1993) Subsurface agricultural irrigation drainage: the need for regulation. Regulatory Toxicol Pharmacol 17:157-180

Lerner DN (2002) Identifying and quantifying urban recharge: a review. Hydrogeology J (in press) DOI 10.1007/s10040-0010177-1

Lim R, Gayle S, Doyle C, Lesjean B, Gibert M (2000) Endocrine disrupting compounds in sewage treatment plant (STP) effluent reused in agriculture - is there a concern? In: Dillon PJ (ed) Proc First Symp Water Recycling, Australia, Adelaide, CSIRO Land and Water, and Australian Water Association, pp 23-28 
Marino MA (1975a) Artificial ground water recharge, I. circular recharging area. J Hydrol 25:201-208

Marino MA (1975b) Artificial ground water recharge, II. rectangular recharging area, J Hydrol 26:29-37

McDonald MG, Harbaugh AW (1988) A modular three-dimensional finite-difference ground-water flow model. Techniques Water Res Invest US Geol Survey, Book 6, Chapter A1

McEwen B, Richardson T (1996) Indirect potable reuse: committee report. Proc 1996 Water Reuse Conf, Am Water Works Assoc and Water Environ Fed, San Diego, California, Feb 1996, pp 486-503

National Research Council (1994) Ground water recharge using waters of impaired quality. National Academy Press, Washington, DC, $382 \mathrm{pp}$

Nellor MH, Baird RB, Smith JR (1984) Summary of health effects study: final report. County Sanitation Districts of Los Angeles County, Whittier, California

Pearce F (1992) The Dammed. Bodley Head, London, 276 pp

Peters J (ed) (1998) Artificial recharge of groundwater, Proc Third Int Symp Artificial Recharge of Groundwater, Amsterdam. AA Balkema, Rotterdam, The Netherlands, $474 \mathrm{pp}$

Peters JH, Castell-Exner C (eds) (1993) Proc Dutch-German Workshop Artificial Recharge of Groundwater, September, 1993, Castricum, The Netherlands. KIWA, P.O. Box 1072, Nieuwegein 3430 BB, The Netherlands

Pyne RDG (1995) Groundwater recharge and wells: a guide to aquifer storage recovery. Lewis Publishers, Boca Raton, Florida, $375 \mathrm{pp}$

Querner EP (2000) The effects of human intervention in the water regime. Ground Water 38:167-171
Rice RC, Bouwer H (1984) Soil-aquifer treatment using primary effluent. J Water Pollut Contr Fed 56(1):848

Sloss EM, Geschwind SA, McCaffrey DF, Ritz BR (1996) Groundwater recharge with reclaimed water: an epidemiologic assessment in Los Angeles County, 1987-1991. RAND, Santa Monica, California, 9407-2138

Soil Survey Staff, US Dept Agriculture (1951) Soil survey manual, US Dept Agric Handbook, No 18, 503 pp

Sumner ME, Stewart BA (eds) (1992) Soil crusting: chemical and physical processes, Lewis Publishers, Boca Raton, Florida, $372 \mathrm{pp}$

Tanji KK (ed) (1990) Agricultural salinity assessment and management. Am Soc Civ Eng Manuals and Reports on Engineering Practice No 71, ASCE, Reston, Virginia

Tatro SB (1999) Dam breaching, the rest of the story. Civil Engineering, April, 50-55

Tyler SW, Chapman JB, Conrad SH, Hammermeister DP, Blout DO, Miller JJ, Sully MJ, Ginanni JM (1996) Soil-water flux in the southern Great Basin, United States: temporal and spatial variations over the last 120,000 years. Water Resour Res 32(6):1481-1499

Van de Graaf AA, Mulder A, de Bruyn P, Jetten MSM, Robertson LA, Kuenen JG (1995) Anaerobic oxidation of ammonium is a biologically mediated process. Appl Environ Microbiol 61(4):1246-1251

Warner WS (2000) The influence of religion on wastewater treatment. Water 21, August 2000:11-13

Warner JW, Molden D, Chehata M, Sunada DK (1989) Mathematical analysis of artificial recharge from basins. Water Resour Bull 25:401-411 